\title{
Number 1.
}

OF

\section{A N N ULOSA JA VA I I CA,}

or

AN ATTEMPT TO ILLUSTRATE THE

NATURAL AFFINITIES AND ANALOGIES

OP THE

\section{I $\mathbf{N}$ S $\mathbf{E}$ C $\mathbf{T} \mathbf{S}$}

COLLECTED IN JAVA BY THOMAS HORSFIELD, M.D. F.L, \& G.S.

AND DEPOSITED BY HIM IN THE MUSEUM OP THE

Fondurable Cast=:3) noia Company.

BY W. S MACLEAY, ESQ., M.A. F.L.S.

SOC. CZES, NAT. CUR. MOSQ. NAT, SCRUTAT, BEROLIN, SOCIUS ET MUS, REG. GALL. HIST, NAT, CORRESP.

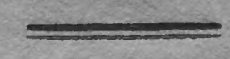

LONDON:

PUBLISHED BY KINGSBURY, PARBURY, AND ALLEN,

LEADENHALL STREET.

1825.

Price 12s. coloured, 10s, 6d. plain. 


\section{EXPLANATION OF PLATE I.}

Fig. 1. Lissauchenius rufifemoratus.

Fig. 2. Pericalus cicindeloides.

Fig. 3. Colpodes brunneus.

Fig. 4. Anaulacus sericipennis.

Fig. 5. Catadromus tenebrioides.

Fig. 6. Dicælindus felspaticus.

Fig. \%. Ephnidius adelioides.

Fig. 8. Planetes bimaculatus.

Fig. 9. Helota Vigorsii.

(N.B. This sheet will be replaced, with the second number, in a form corresponding with the work.) 

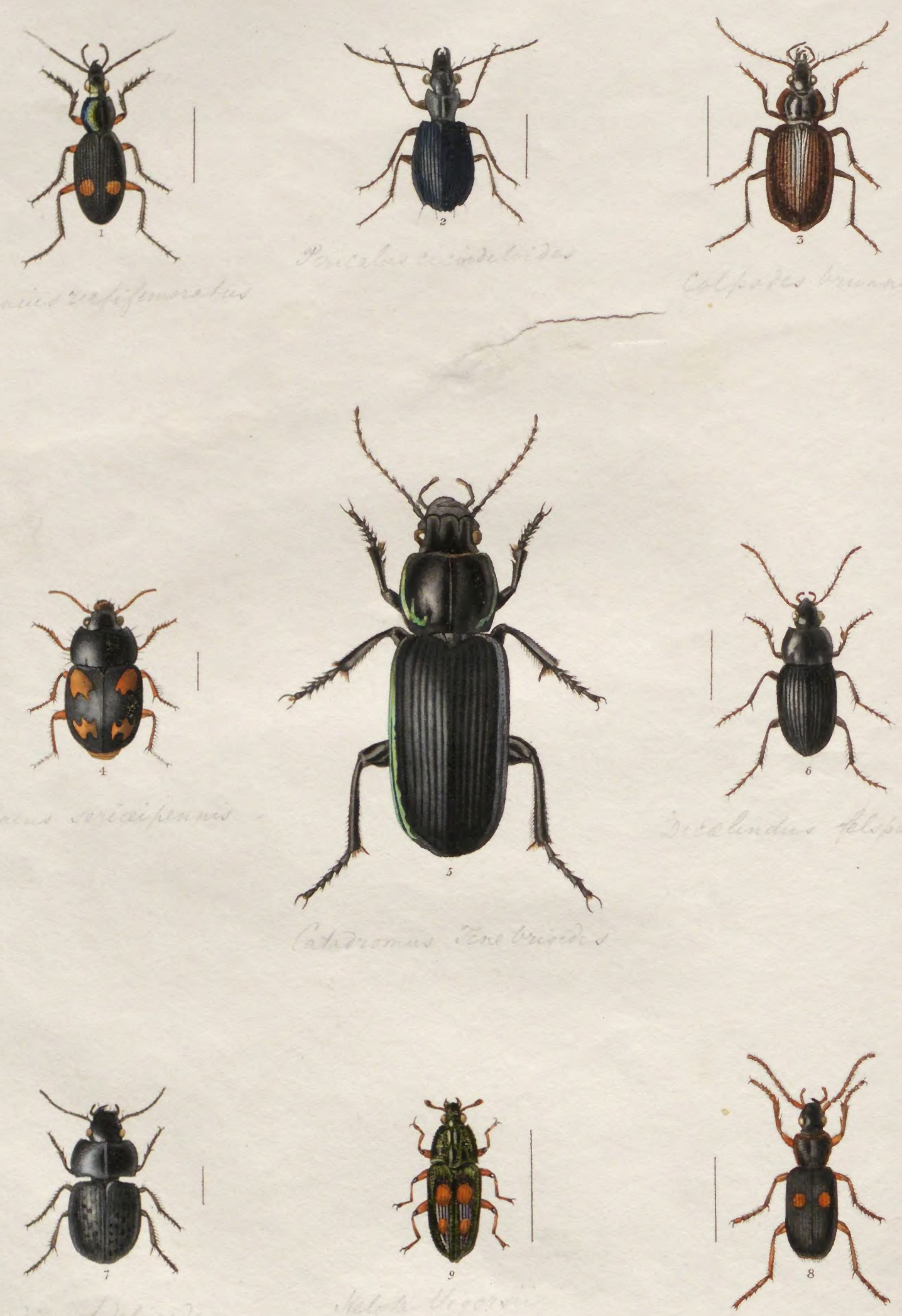
TO THE

\section{HONOURABLE THE COURT OF DIRECTORS}

OF THE

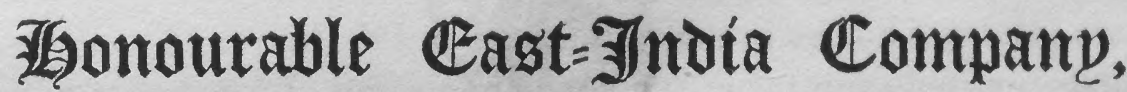

\section{THIS WORK}

IS, WITH THEIR PERMISSION, RESPECTFULLY DEDICATED,

BY THEIR OBEDIENT SERVANTS,

WILLIAM SHARP MACLEAY, AND

THOMAS HORSFIELD. 


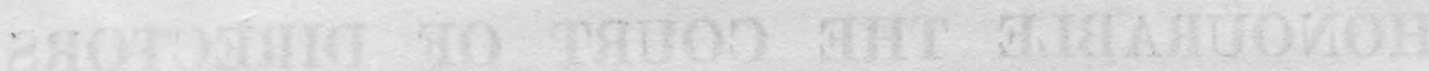

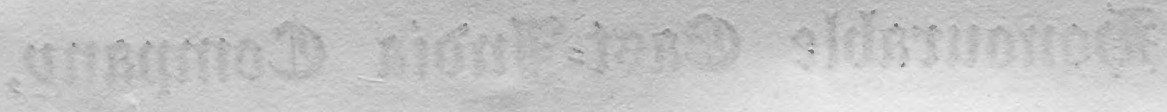

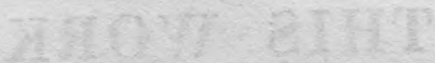

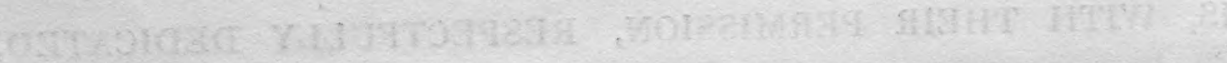

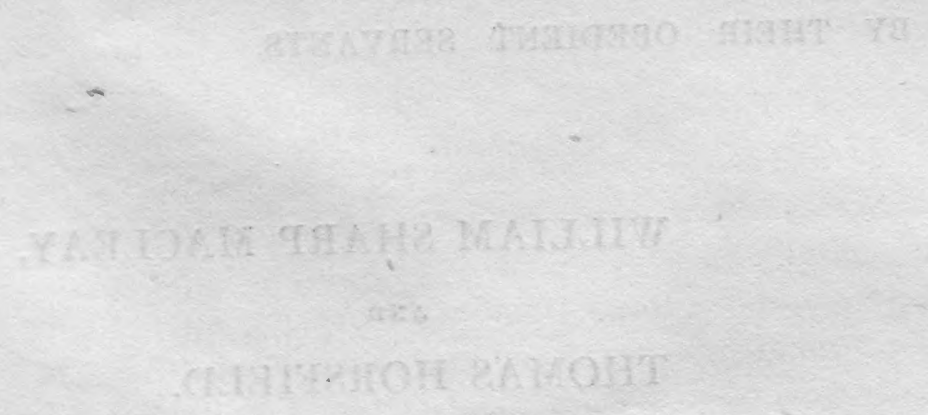




\section{P R E F A C E.}

Fon several years after his arrival in Java, the principal pursuits of Dr. Horsfield were Botany and Materia Medica, but as numerous insects were constantly occurring to him during his botanical excursions, he was naturally and almost imperceptibly led to the collection of these beautiful and interesting animals. Like most other entomologists he commenced his career in the science by paying attention to Lepidopterous insects, to the collection of which he was the more induced by their great abundance in certain districts, during the latter part of the rainy season. The Coleopterous and other insects, which have been deposited by him in the East-India Company's Museum, were principally collected towards the end of his residence in the island, which he finally quitted in $181 \%$, on its being ceded to the Dutch.

In the year 1812, or soon after the conquest of Java by the British arms, Dr.Horsfield's original plans were considerably enlarged, in consequence of the liberal patronage which was bestowed on his researches, by the Honourable East-India Company, through the friendly medium of Sir Stamford Raffles, the Lieutenant-Governor of the Island. At this time Dr. Horsfield was established in an extensive plain, elevated nearly 200 feet above the level of the ocean, and situated near the middle of the island, in regard both to its length and breadth. This plain is highly fertile, and with very little exception, is in a complete state of culture. The soil is a deep vegetable mould which, near the banks of several large rivers that flow through it, is mixed with sand. Here the collection of insects was carried on with zeal and perseverance, not only by Dr. Horsfield himself, but by various native assistants, who had been properly trained to this pursuit. His attention, as may be conceived, soon extended itself to all Annulose animals without exception, and his assistants were accordingly instructed to look for them in every situation, and as far as possible, to leave no place unexamined. During these researches, therefore, the party being provided with all the usual implements of entomological collectors, neglected none of the ordinary resorts of insects, such as flowers, decayed wood, carcases of dead animals, ponds, \&c., and consequently, the collection now in the possession of the East-India Company, may very fairly be considered as affording a general view of the entomology of the above-mentioned plain. When any remarkable deficiency is observed in particular natural groups, we may at least conclude, that such insects are on this plain comparatively very rare. According to Dr. Horsfield's general observation, indeed, those insects which live on plants, 
shrubs, and trees, are extremely abundant in Java; while such as in more temperate climates are commonly found in various situations near the surface of the earth, are limited to a few families. At the same time, however, it may be well to bear in mind, on regarding the immense proportion of herbivorous insects in the collection, that from the nature of Dr. Horsfield's more immediate pursuits, he was particularly led to collect on plants.

From the plain just mentioned, in which, on account of the extension of agriculture and a numerous population, the variety of vegetable and animal productions is neces. sarily limited, Dr. Horsfield often made journeys, in different directions, through the more wild and uninhabited parts of the island. Some of these were undertaken almost exclusively for entomological research, and were particularly directed at the proper seasons to a long range of hills extending parallel to the southern coast of the island, and rising to an elevation of 2,000 feet above the level of the ocean.

The base of this range is of a mixed nature; partly calcareous, partly trappean, and the hills are covered with trees and shrubs, although in many places the vegetation is less abundant and luxuriant than in the volcanic district, which constitutes a long series in the centre of the island. The great bulk, however, of the Coleopterc to be described in the following pages, was collected in the southern ranges, or on hills of nearly the same elevation, near the foot of the large volcanos, in the centre of the island. And here may be stated a curious circumstance in entomological geography, observed by Dr. Horsfield, namely, that the temperature which exists from an elevation of 1,000 to that of 2,000 feet above the level of the ocean, is most productive in Coleopterous insects ; and, consequently, that this order occurred most abundantly in the southern and lower central ranges. The Lepidoptera, on the other hand, appeared to be most abundant at an elevation of between 3,000 and 4,000 feet, that is on the declivities of the high volcanic peaks. On such lofty situations, the lixuriance of vegetation greatly exceeds that of the southern ranges; and here, at the height of neariy 4,000 feet above the level of the sea, multitudes of the most brilliant and rare Lepidoptera were taken, and from the quantity of larvæ observed by Dr. Horsfield, he conceives that many more species remain still to be collected.

If the collection can be considered defective, Dr. Horsfield imagines that it is only seanty in such species as may be peculiar to the districts which extend from the immediate confines of the ocean to an elevation of 200 feet. On the south coast the hills rise so abruptly from the sea to an elevation of several hundred feet, that probably few species were lost by these shores not having been examined; but along the northern coast of the island, which in many cases is low, and bounded by extensive plains of sand, there possibly remains much to be discovered. 
It may therefore be stated in recapitulation,-1st. That this collection affords a general sample of such Coleoptera and Lepidoptera as are to be found in the extensive plain which is situated south of Samarang (one of the principal towns on the northern coast), and which extends from the declivities of the mountain Merapi, in the west of the island, to those of the mountain Lawu, in the east.

2dly. That in frequent excursions made from the capital Suracarta (which is situated in the plain above-mentioned), towards the eastern and western boundary of the native princes territory, and towards the ranges extending along the southern coast of the island, both Coleoptera and Lepidoptera were carefully sought after, but were almost exclusively collected on plants.

3dly. That the fertile acclivities of the volcanic series, extending longitudinally through the centre of the island, and covered with a profusion of the most luxuriant vegetation, have afforded a large proportion of the Lepidoptera in the collection; while in the western extremity of the island, which comprises many uncultivated tracts of country highly productive in insects, the opportunities which Dr. Horsfield possessed for collecting were comparatively limited.

From what has now been stated, it must sufficiently appear that this collection is not brought under the notice of the public as a complete one. Many species indeed have lately been described from the continental collections as inhabitants of Java, which will not be found in the following list; and it is possible that many more still remain undescribed in the cabinets of the King of the Netherlands, M.M.Westermann, Reinwardt, \&c. But this much may be said with the strictest truth, namely, that Dr. Horsfield has brought to England so fair a sample of the Entomology of Java, that if it be deficient in several species, it is probably not deficient in many peculiarly new forms. And if so much can be said of the extent of our materials, still more may be promised with respect to their intrinsic value; for Dr. Horsfield will be found to have paid such attention to the metamorphoses of Lepidoptera, as has enabled him to bring to the shores of Europe a more valuable mass of entomological information, than had ever hitherto been collected within the tropics.

Having thus given an outline of the mode and localities in which this valuable collection was made, and some notions with respect to its extent, I may be allowed to say a few words on the plan of descriptive catalogue that has been employed to make thespecies known.

Scarcely one of the many voyages and travels which at present teem from the press, is considered as scientifically ushered into the world, unless it be accompanied by an appendix containing descriptive catalogues of the animals or plants which may have occurred in the course of the expedition. The nature, use, and proper object 
of such catalogues become, therefore, questions not altogether without interest. A descriptive catalogue in Natural History is nothing else than a list of species, accompanied with such descriptions as may be judged sufficient to make these species known; and it is evident that a number of various catalogues, having very different objects in view, may be drawn up to correspond with the terms of this definition. A catalogue, for instance, may be formed like that of Buffon, with an express contempt of technical nomenclature and a thorough disregard of system; the interest of the work depending wholly on that of the history of the individual species described, and the fecundity of imagination, or floridness of style with which their respective manners are developed. Such is, so far as concerns true science, the least profound, and therefore the most ancient sort of descriptive catalogue; although indubitably it is in certain cases quite sufficient for the purpose of making known the animal intended to be described. Thus, considering the horse merely as a domesticated animal, no scientific description can so eloquently, so admirably depict it as that of Buffon, and yet from such a description, we gain no notion whatever of the place which this noble creature holds in the great plan of creation. For all that we learn by it, there need scarcely be more than two insulated beings in the world, man and the horse. The consequence is, that such catalogues only suit for giving popular accounts of a few of such remarkable plants and vertebrated animals, as are directly connected with the habits of man. They seem to proceed, not only on the idea of all design, all order being absent in the creation as a whole, but also as if the infinitely greater part of organized forms need scarcely have been created. It would be absurd, even if it were possible, which it certainly is not, to adopt such a plan of catalogue for the description of insects or shells; for the interest taken by the public in these "Animated Natures," depends either on the number of anecdotes they contain, or upon our having already, in the usual course of life, acquired directly or indirectly some notion of the animals described, and therefore some curiosity to know more of their manners. Such a catalogue, therefore, is truly unscientific; but at the same time, and certainly for this reason it is the most popular of any. To understand it requires no previous acquaintance with Natural History; and to read it, we are told, is all that is necessary for the common purposes of life. True indeed it is, that a horse, a dog, a bee, any animal in fact which is already interesting to us from its immediately affecting the interests of man, may in this way be described, so that every characteristic trait, every particular of their manners shall be detailed: and yet it is easy to prove, that both tixe reader and writer of such descriptions may remain utterly unacquainted with Natural History as a science. They know no more ot it, necessarily, than that person knows of astronomy who may have observed the change of seasons, or the difference in the length of days and nights. 
nights. Buffon himself, to whom such catalogues owe their chief reputation, was more properly the historian of a few natural objects, than the "Historian of Nature." This, perhaps, to the generality of readers, will appear a bold assertion, when directed against a man so celebrated; and may indeed startle any person who has been accustomed to allow the following parallel to be correctly drawn. "Linnaus saisissoit avec finesse les traits distinctifs des elres; Buffon embrassoit d'un coup d'ail les rapports les plus éloignés." But I confess that the truth of this distinction, so indisputable in the eyes of French naturalists, has never yet been apparent to me; and so far from attributing general views of the plan of creation to Buffon, in preference to Linnæus, I do not conceive that the mode in which he studied Natural History, could ever have led him beyond a well-written "Animal Biography." It is not indeed asserted, that Buffon was destitute of general notions on the creation; for this with a man of genius, looking at so divine a work, was impossible: still less is it asserted that he was deficient in the powers of generalizing; but what I mean is, that his ideas of nature were from the foundation wrong, his mode of studying her works erroneous, and his general conclusions, therefore, almost always false. For the truth of my position, I have only to refer to those parts of his works that touch on what is truly the science of Natural History: as for instance, to take one of the most profound of them, his account of birds that have not the power of flying. All that can be said in favour of the above distinction, is, that if Buffon had an eye for seizing any relations of affinity, they were indeed "les plus éloignés." Leaving, therefore, such a plan as his to those inventive imaginations, those crude theories, and that pompous flowery style, which can alone give it any peculiar interest, the modern writers of Faunce or Flora, have invariably been obliged to resort to systematic descriptive catalogues. All of these however may, I conceive, be reduced to two kinds-those which are founded on artificial systems, and those which are grounded, not on any particular artificial system, but on the endeavour to disco. ver the natural system. Of the first kind, that is, of those which are drawn up according to the pre-conceived importance of some one or two particular organs, is the justly celebrated Systema Natura of Linnæus.

We have seen that by such a plan as that of Buffon, it would be impossible to make known the forms of every insect, shell, or moss, that may occur in distant coun. tries, and recourse is therefore had to a systematic cataiogue wnich, by referring to the arrangement of some classical work, such as the "Systema Natura," or the "Regne Animal," enables the traveller at once to give a name to the object he describes, and the reader to know it by that name. The advantage of such a descriptive catalogue is, that to scientific characters and technical descriptions, written with the precision of Linnæus, may thus be subjoined the histories of the rarest animals, written with the eloquence 
eloquence of a Buffon. While, therefore, it records the manners and economy of such beings as most directly affect our habits of life, it also admits that of which an unscientific catalogue is incapable; namely, the means of making the lowest animalcule or lichen of a distant country, nearly as well known to us in point of form, as a horse or an oak. A systematic descriptive catalogue, founded on an artificial system, is indeed very convenient for the description of newly discovered animals, when the principal object in view is the possibility of their being useful or injurious to us in the course of life. Those fire-side travellers who limit their researches in Natural History to such points, as being acquainted with the forms of the cereal plants used by the peaceful Hindoos, or with those of the animals eaten by the savages of the Polar regions, require nothing more than this species of catalogue; and so far all may be right. But if we descend to the description of minute mosses or insects on this plan, it is difficult not to imagine that our leisure hours might have been better employed. Unless it be for killing time, it is difficult to conceive what possible purpose it can serve, to name and describe some thousands of minute insects and shells, which we may never see but in the cabinet of a collector. Certain insects, indeed, may attract a portion of attention on account of the uses to which they may be applied by man, or the injuries which they may inflict on him. Thus the cochineal insect of America, or the destructive locust of Africa, may excite some share of interest in the general reader of an entomological systematic catalogue; but these are only drops in a vast ocean of species, and the writer of such a catalogue, founded on an artificial system, must, when he has done his best, content himself with the credit of having enabled some virtuoso to give barbarous names to a few dried beetles.

If, however, a descriptive catalogue can be formed, not resting on the preconceived importance of any particular organ or organs, but, on the manner in which the whole animal structure varies, and having, therefore, for its object the discovery of the general plan of creation, it is obvious that the lowest insect or polype derives importance from this object. Organized nature is a complicated chain of beings, of which chain each species forms a link. Every new species added to our list, serves thus to increase our knowledge of this stupendous system, - a system that ought to excite in every breast the most intense interest; not merely as one of the works of our Creator, but as that particular work of the Divine Hand, which has been designed with direct reference to ourselves. A minute beetle of Java, therefore, which of itself scarcely raises a thought in our minds beyond what may originate in its splendour of colour, or its eccentricity of form, becomes absolutely important when described in reference to its fellows. Not, indeed, that with respect to the particular fact itself, the world need care much to know that some tribes of beetles are constructed on a plan beautiful and regular beyond measure: but when, in consequence of this knowledge, a similar beauty and 
regularity are detected in other branches of the organized creation, even in that with which we ourselves are immediately connected, and the presumption thus arises that they extend throughout nature; then at least ought naturalists to attend to this delightful field for discovery, and by none ought it to be despised. Those who take up the subject in this light, will even excuse the entomologist for making insects the particular object of his study, in preference to the other branches of nature. Entomologists indeed, when their researches are properly directed, may truly say with the poet,-

$$
\text { "In tenui labor, at tenuis non gloria." }
$$

For it is among insects, above all other groupes of animals, that, owing to their myriads of species, the mode in which nature's chain is linked-a mode, the knowledge of which comprizes all knowledge in Natural History-will be most evident, and therefore most easily detected. Nay, with a view to the discovery of the natural system, a local descriptive catalogue of insects, arranged according to their natural affinities, is more useful than a descriptive catalogue of Vertebrata on the same plan; and this, because the comparative paucity of vertebrated species in a given place will render such a catalogue infinitely more disjoined, than any similar list of Annulose animals ever can be.

It is obvious also, that such a catalogue may contain vivid descriptions of such animals as of themselves are interesting to mankind, while it admits of even more scientific precision than the most copious of those which are founded on artificial systems. The very situation of an animal in a catalogue, which is arranged correctly according to natural affinities, may point out a thousand particulars, both of its economy and structure, that could never have been arrived at by the most elaborate description.

The sole disadvantage attending this sort of catalogue is, that it ceases to be a dictionary of nomenclature, to which a perfect tyro in entomology may, with certainty, resort for the name of any insect he has collected. And, undoubtedly, if a person be unacquainted with the Linnean genera of insects, I fear that he will not be able to make much use of the following observations; but if, on the other hand, he should know these genera, he can, in my opinion, have little difficulty in comprehending every thing liere stated.

I am not aware that any local descriptive catalogue of insects has ever yet been attempted, with reference to the discovery of a natural arrangement, unless, perhaps, it be the admirable Monographia apum Anglice; but even the plan of this work had only reference to a few Hymenoptera, and consequently, was inapplicable to other insects, and much more so to all other animals. The reader will, therefore, take into consideration the difficulties I encounter in commencing a catalogue of insects, on a plan of investi. 
gating Affinities and Analogies which is conceived to be applicable to the whole of organizedmatter. The most comprehensive view that, in this world at least, man can ever take of nature, must be but a glimpse of the reality, and must, consequently, be always sus. ceptible of infinite improvement. As yet, moreover, we have not even arrived at the threshold of nature's temple; so that I shall have attained the utmost I can hope for, if I should be found to have made a nearer approach to it, than had ever yet been made in the same branch of entomology. The attention of naturalists in different countries, and in widely different departments of Natural History, havinglately been turned towards the laws which regulate the distribution of organized nature, and their works in general being easily referred to, I shall not in this place enter into the theory. The staunch partizans of Linnæus, however, - those who account the Systema Natura to be Nature's system,-will not be displeased to find, that in the following pages the Linnean genera of Coleoptera, even those which, by Fabricius and Latreille, were most widely broken asunder, now again become groupes, and this merely by following the filum ariadnoum of affinities, and certainly without any remarkable partiality on my part to the learned Swede's character as an entomologist. It cannot, however, be denied, that almost in every case his genera are natural groupes, although he erred in making them all of the same rank, and appears to have had no idea whatever of the manner in which they are connected.

I have only now farther to observe, that it shall be my earnest endeavour to render this work useful to persons resident in the Indian Archipelago, not merely by enabling them to know the species they may meet with, and so to commence a science which may eventually prove an agreeable source of amusement; but by informing them of the circumstances to which they ought to pay most attention, and thus making their labours tend to the development of the plan of creation.

My next and principal endeavour shall be not only to render the Javanese species of Annulosa known to European collectors, but to shew the places which they respectively occupy in the scale of created being. In the meanwhile let the young naturalist bear in mind, that it is not the ready ability to give a name to an object, which ought to be considered the grand, the ulterior aim, the "ultimus finis" of his observations, but, as Linnæus says, the discovery of the natural system; and of this the meanest atom that lives, the Monas itself, may perhaps form a link as necessary towards our proper compreheusion of the whole, as any other animal, however large, or however intelligent. 


\section{AN NULOSA JAVANICA.}

\section{INTRODUCTION.}

As this Work is to be conducted with as much reference as possible to those general principles of natural distribution which I have laid before the Public, both in the Hor a Entomologica and the Transactions of the Linnean Society, the rearler may easily perceive that there will be some novelty in the arrangement, as well as in the matter arranged. In abandoning, however, that division of Coleoptera which is founded on the number of joints in the tarsi, and which has acquired so much vogue on the Continent, it may be necessary to shew that I am countenanced by some authority. I slall, for this purpose, therefore, content myself with citing the following words of M. Latreille: that is, of the distinguished naturalist to whom the Tarsal System owes much more of its celebrity than to its inventor. "Articulorum tarsorum progressio numerica decrescens in methodo naturali non admittenda."-(Gen. Crust. et Ins. vol. i. p. 172.)

It will also be seen that I commence with the Adephagous Coleoptera, not indeed because they form a particularly rich part of the Hon. East-India Company's collection, and still less from any notion of the Linnean genus Cicindela having a peculiar title to this pre-eminence, but because they constitute that department of the science which at present most engages the attention of Continental Entomologists. In the course of this investigation I slall have several new genera, or rather sulggenera, to propose, of which the characters in some cases must necessarily rest on refined, and even minute considerations. Now, as the object $I$ have in view is to make known in a definite manner all the species that may be new, I cannot hope to carry this my intention into execution without adopting some of those delicate distinctions, which result from the mode of investigation that has lately been pursued by M. Bonelli, in his study of these insects. I have, indeed, little choice to make : for I must either expose myself to a charge very frequently at present brought against Entomologists-namely, that they disgust persons with the science by the multitude of names with which they load it; or I must display unpardonable ignorance of the many excellent observations which conld never lave been discovered, nor can now be explained, without such a mode of discrimination being resorted to. When, therefore, I venture to add to the already overwhelming number of subgenera into which the Linnean grenus Carabus has been divided, I have to state in excuse, that this course of proceeding is adopted from the conviction that it is impossible to assign some of the new Javanese forms to any of those genera, which MM. Dejean and Bonelli have almost entirely founded on the examination of European 
insects. If, in short, new subgenera are here made, it is because otherwise $\mathbf{I}$ should have had either to refer all the new Javanese insects to European subgenera, with the characters of which they do not agree; or to assign them to large groupes, where the Entomologist would have had to search for them among some hundreds of species, and at last have ended his toil with complete uncertainty as to their identification.

If my subgenera were in every case natural, or if I could in every case display their true place in the series of affinity, I should as little think of offering an apology for minuteness of investigation, as my readers would expect it. In that event, a sufficient answer would be, that certain affinities were pointed out by such minute discrimination, while the resulting series was natural ; but this I am sorry to say cannot be pretended in every case, and particularly in that of one of the families into which the Linnean Carabus shall here be divided. Consequently the new subgenera of this family, viz. the Harpalidce, must rest their stability first on their own merits, as serving to make new forms definitely known; and secondly, on the little value of every argument that has hitherto been used to prove the minuteness of modern Entomological genera. Indeed, on this last head I cannot refrain from calling the reader's attention to a few curious facts, which will serve to illustrate an argument that has already been ably sustained by $\mathrm{Mr}$. Spence, in his monograph on the genus Choleva.

There is nothing which makes the fertility of design that has characterized the Creation so incontestably evident, as the variation of structure that sometimes prevails in groupes of an inferior rank, such as genera or families. It is indeed manifest, that if a groupe like the Vertelirata be of a primary degree, and the uumber of species it contains be nevertheless small, then the divisions will be more decided and more easily seized than if the number of species were great. But if the groupe be not of a primary nature like the Linnean genus Carabus, and yet the number of species contained in it be great, then the difficultics of distribution are augmented, owing to the number as well as to the minuteness of the differences to be seized. And yet it is such difficult ground that we ought in a particular mamer to cultivate, if we wish to attain a true knowledge of nature; and this remark truly deserves attention from those who object to that delicacy of rescarch which has characterized the labours of MM. Clairville, Bonelli, and Dejean, among the Harpalida. The distinctions of these Entomologists are, it is true, often minute; but when we observe that the groupes characterized by such distinctions contain twenty, thirty, sometimes more than a hundred species, we necessarily say that, for the sake of convenience alone, it were to be wished that even these groupes, minute as they are, could be subdividerl. But while this delicacy of discrimination is useful for the artificial purposes of nomenclature, it becomes indispensably necessary in the study of affinities. More than 1600 species of the Linnean genus Carabus have, for instance, colne within my own knowledge. Now, supposing a new species to occur, which indeed happens every day, what definite idea of its structure or affinitics can possibly be obtained by a person who refers it to a groupe of 1600 beings of so many various forms? And if these 1600 species compose but one genus, as they do according to Linnæus, what person can be found with either time or inclination to identify the specific name of one of them ? Indeed, this circumstance of itself has rendered the identity of many species of Linnæus, and even of Fabricius, quite uncertain. For example: "Carabus alatus ater nitidus, elytris striatis antennis rufis" (Fab. Syst. Eleuth. vol. i. p. 189) is a description that will apply to hundreds of insects, of 
structure, economy, and appearance all totally different from each other. On this account, therefore, Clairville and Bonelli merit the greatest praise for the assiduity and perseverance they have shewn in the study of the Harpalida. Their labours, however, soon gave rise to the complaint that every species was thus becoming a genus, and that confusion instead of order was thus arising from their innovations. This complaint, indeed, has gradually died away among Entomologists; but it has, in consequence, become a charge levelled generally against Entomology, by certain persons who are ignorant of the present state of the science. The genus Carabus of Linnæus has, above all others, given rise to such charges; and it must therefore not a little surprise these critics to know, that after all the various mutilations which the genus Carabus of Bonelli has undergone, it appears in the collection of M. Dejean, whose catalogue, be it remembered, is very far from being extensive in extra-European insects, to contain about twice as many species as Linnæus las described of his genus Carabus. In the 13th edition of his Systema Naturæ, the latter describes only forty-three of his genus Carabus, which is a groupe of four modern families; whereas Baron Dejean's collection contains eighty-three species of the modern genus Carabus; and I know of about forty more. No genus call rest on more refined considerations than the genus Harpalus, as it at present stands; yet Dejean's catalogue contains ninety-two species, of which sixty-three are European. On looking at this catalogue, we find that the average number of species Baron Dejean possesses in cach of his eighty-six genera made out of the Linnean genus Carabne, is teu; that is, the same number which Persoon, in his last edition of the Synopsis, describes in each of his 2280 genera of plants; and yet, as Decandolle lias well observed, in the Théorie Elémentaire de la Botanigue (p. 222), Persoon las in reality fewer genera, in proportion to the number of plants he knew, than Linnæus; for while the former assigns ten species to each of 2280 genera, the latter naturalist only allows six species at an average to each of 1260 genera. So that if 1500 species of Linnean Carabus exist in collections, we may donble the number of published subgenera, and yet allow fewer subgenera, in proportion to the number of species we know, than Linnæus did of genera in that portion of nature with which he was best acquainted. So much for the observation that every species is now a genus in Entomology, -an observation that has lad its origin entirely in the inadequate idea generally prevailing as to the number of annulose species which exist. We every day hear of the difficulty of natural history having increased, and doubtless it is increasing every hour: but this is owing to the number of new species which are pouring in upon us. Still a great advantage has accrued to the science from the augmentation of our collections; for if the study of natural affinities was formerly impossible, it has now come within the reach of every persoll who does not allow himself to be frightened by the multitude of names which necessarily crowd the pages of the best modern works on natural history. Names, after all, are only formidable when marshalled in an index; and the difficulty they present to the young naturalist not only vanishes when it is encountered, but soon is found to be his best aid, in combating difficulties of infinitely greater importance.

With respect to my general distribution of Clairville's Adephaga, I have little more to say, than that it is a sketch of natural affinities which the reader of the Horce Entomologica will find to illustrate certain questions there left in doubt. And if $I$ have not been able to adopt that exposition of these insects which has lately been given to the public by my friends MM. Latreille 
and Dejean, it has at least been as closely attended to as I judged either consistent with nature or convenient for use.**

Some of the new subgenera here proposed being founded on external characters, it may be necessary to premise, that where the specimen was unique or very rare in the collection, I had not, of course, the permission to dissect it. I hope, therefore, that this circumstance will be taken particularly into consideration, by those who may have occasion to refer to the following descriptions, which I shall now proceed with.

* I have not, for instance, thought it advisable to lay so much stress on the form of the external joint of the palpi as these gentlemen have done. The validity of my reasons for differing from them in this respect may be judged on a perusal of P. i. p. 4, Horæ Entomologicæ. As to the general distribution of M. Latreille, it is confessed by himself to be artificial, and therefore I need offer no apology for abandoning it. 


\section{COLEOPTERA.}

Av attempt has been made in the Horce Entomologica to shew that if we gradually limit our views, and descend from the consideration of the kingdom Animalia to the department or subkingdom Annulosa, from this again to the class Mandibulata, and then to the order Coleoptera, thus leaving each groupe for one of its component minor groupes, we shall at length observe the last-mentioned, viz. the order Coleoptera, to resolve itself into five minor groupes, which I have termed tribes. Now one of these tribes consists of insects having Chilopodiform larva; that is, their larva are carnivorous, having their head furnished witl ocelli and strong mandibles, generally pierced for suction. Their body is subdepressed, composed of angular, or at least of laterally incontinuous segments, of which all, or at least a certain portion, are each covered with a corneous lamina. Some one of the hinder segments of the body (in general the penultimate or last) is noreover always furnished with at least two styliform appendages, which are sometimes corneous, sometimes membranaceous, and sometimes articulated. From this general resemblance of the larvæ to young Chilopoda, the tribe may be termed

\section{CHILOPODOMORPHA. Character Typicus.}

LARVA chilopodomorpha plerumque carnivora, corpore processubus duobus posticis styliformitus dorsalibus seniper instructo.

Imago plerumque pentamera, mandibulis corneis, maxillis bipartitis vel processubus duobus; lacinia interiori in unguem corneum incurvum fere semper desinente; lacinia exteriore sapius biarticulatả interdum palpiformi.

I have elsewhere shewn that nature appears to have varied less in the structure of the maxillæ than in any other part of the mouth of Coleoptera, and have consequently inferred that the Entomologist ought to pay particular attention to the form of the maxillæ in the perfect insect. In the tribe having Chilopodiform larvæ, we have a remarkable example of the truth of this reasoning, for a particular modification of that form of maxillæ which is general to this tribe caused the carnivorous insects, or Adephaga of Clairville, to be early separated from all other Coleoptera by a most anomalous character, viz. that of having six palpi. When Savigny, however, reduced to one general structure the mouth of all winged insects, it followed as an immediate consequence, that Coleoptera do not differ so much among themselves as that two or three families should have four maxillary palpi and all the rest only two. We find, accordingly, that a more philosophical view of the subject did not fail to be taken by M. Latreille, as soon as he had weighed with due consideration the theory of M. Savigny.* For instance, the maxillæ of Coleoptera may be described generally as being composed of several pieces which are often entirely confluent, and generally so far confluent as to form one mass; the interior palpi (as they are called) of adephagous insects forming almost the only known exception to the rule. But even

* Nouveau Dictionnaire d'Hist. Nat,, art. Bouche, p. 242. 
in this case the proper view of the maxillæ is, that they terminate in two lobes, generally ciliated, and often confluent, the external lobe being in its typical state connected with the internal lobe by an articulation, and the internal lobe being terminated by an unguis. Of this typical maxilla Passalus affords a good example; ${ }^{*}$ and among the Petalocera, we find it distinguishable in the whole family of Geotrupida. We have an example of the confluence of the maxillary pieces, that is, of a complete departure from the typical maxilla, in AEgus; and, indeed, the Thalerophagous Petalocera in general, but particularly the Anoplognathide, exhibit little or no traces of the above typical structure of the maxilla.

The Maxilla of such Coleoptera as have Chilopodiform larvæ, possesses, however, a peculiar character, which may be considered as typical in reference to the groupe. The external lobe is not only connected with the internal by an articulation, but itself consists of two pieces. Sometimes, as in the Linnean genera Cicindela, Carabus, Dytiscus, and Gyrimus, this biarticulate external process of the maxilla is slender and cylindrical, and consequently palpiform, occasioning these genera to be characterized as having four maxillary palpi. Sometimes, as in the Linnean genera Hydrous $\uparrow$ and Staphylinus, $\neq$ this biarticulate process is dilated and not palpiform. Sometimes again, as in certain species of the Linnean genus Silpha, the two pieces which form the external lobe of the maxilla are confluent or soldered together, although the typical structure remains visible, or the outer piece is converted into a penicilliform lacinia, adapted to the particular economy of the insect.

The tribe of Chilopodomorpha is divisible as follows, into five stirpes i.e. races; or, which is the same thing, into two groupes; one of which contains two stirpes, and is typical of the tribe; while the other contains three stirpes, more immediately conducting to other tribes, and which may therefore be termed aberrant.§

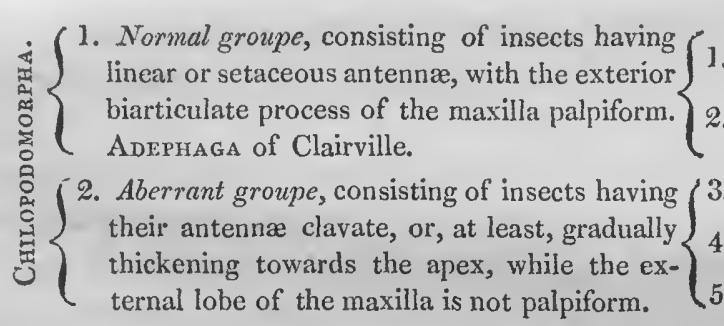
Stirpes.
Exempla typica.
1. Geoderhaga ................Carabus.
2. Hydradephaga........... Dytiscus.
4. Philhydrida ................. Hydrophilus.
4. Necrophaga (Lat.) ... Silpha.
5. Brachelytra (Lat.) ... Staphylinus.

That this tribe is a natural groupe, sufficiently appears from the above series of five stirpes returning into itself, and forming as it were a circle. Thus, from the Geodephaga, or genera Cicindela and Carabus of Limnæus, we pass by means of Omophron to the Hydradephaga, or genera Gyrinus, and Dyticus of Linnæus. From these again we pass to the Linnean genus Hydrous, which, until his entomological career was nearly over, the great Swede confounded always with Dyticus. Part of the Philhydrida, such as the modern genus Elophorus, was by

Limnæus

\footnotetext{
* For this and the following examples, the reader may consult the figures given in the first part of the Horce Entomologica.

+ Hydrophilii Lat. Gen. Ins. et Crust. vol. ii. p. 62.

土 Kirby, Lin. Transact. vol. 14, p. i. p. 100.

$\oint$ The terms applied by M. Fries to such groupes, viz. centric and radiant, I have not thonght proper to adopt, for reasons that will be found at length in the Transactions of the Linnean Society, Vol. 14, p. 59.
} 
Linnæus placed in his genus Silpha, to which, without doubt,Elophorus approaches by some of the less typical insects of that groupe, which M. Latreille, in the Genera Insectorum, has named Necrophaga. From the Necrophaga we pass by means of Micropeplus to Staphylinus, * and then Lestevas (the Carabus staphylinoides of the Entomologia Britannica) will serve to conduct us back again to the Terrestrial Adephaga.

I now proceed to the consideration of that normal groupe of the Chilopodomorpha, which is the same with the

\section{COLEOPTERA ADEPHAGA of Clairville and Latreille.}

\section{Character Essentialis.}

Maxilla labo interno unguiculato, ungue interdum articulo inserto; lobo externo palpiformi scepissime biarticulato, qud de causd sex palpos apud Adephaga quidam enumerant.

The Adephaga of Clairville compose one of those dichotomous groupes which M. Fries would term a centrum. They are remarkable for having been characterized as possessing four maxillary palpi, two to each maxilla. This excellent characteristic may, however, as above explained, be more accurately understood by accounting all Culeoptera as having only two maxillary palpi, and the Adephaga to be only peculiar in having a biarticulate process to the maxilla, which in some species is degraded to a mere spine. The typical structure of the maxilla in adephagous insects seems to be that of the Cicindelida, where this organ has both the external and internal lobe biarticulate. In all the other Chilopodomorpha the external joint of the internal lobe, when it exists, is as in Cicindela, unguiform, but confluent with or soldered to the first joint.

These predaceous insects evidently form two very natural groupes, viz. the Terrestrial and Aquatic Adephaga, the former of which is nuch more numerous in species than the second.

\section{A. GEODEPHAGA.}

Adephaga Terrestria, Lat. Carabus et Cicrndela, Lin. Pedes tantummodo gressorii. Corpus oblongum raro ovatum. Pedes postici motu horizontali et verticali; lamince pectorales quibus inseruntur mugnitudine mediocres.

\section{B. HYDRADEPHAGA.}

Adephaga Aquatica, Lat. Dyticus et Gyrinus, Lin. Pedes natatorii. Corpus avatum. Pedes postici motu tantum horizontali; lamina pectorales quibus inseruntur maxima.

If the five following families of terrestrial Adephaga, which coincide with those of MM. Latreille and Dejean, be natural, then the subdivision of them will probably depend on the form of the mentum, which deserves particular attention. But although I believe the following table to be a very near approximation to the truth, I an inclined to think that the accurate demarcation of the respective families depends on the forms of the larvæ. 'Thus, the Cicindelidce and Carabide are distinguished from all the other terrestrial Adephaga, in having the styliform appendages to the body of their larvæ corneous; but the Cicindelide have them dorsal and affixed to the eighth segment of their body, in order to suit their mode of life; whereas, the Carabida have them caudal.

* "Sous quelques rapports les Brachélytres avoisinent les Adéphages et sous plusieurs autres les Boucliers et les Nécrophores."-Lat. Règne Animal, vol. iii. p. 216. 
caudal. That the other three groupes of terrestrial Adephaga may be distinguished by their larvæ in like manner, I infer from a circumstance recorded by M. Latreille, who says, that the larva of Aristus has the form and manners of the larvæ of Cicindelida, a circumstance perhaps only to be accounted for on those principles of natural distribution which I have explained at length, Horæ Entomologicæ, Part ii. p. 518.

\begin{tabular}{|c|c|c|c|}
\hline $\begin{array}{l}\text { 1. Normal groupe. } \\
\text { ibiæ anticæ haud emarginatæ. }\end{array}$ & $\begin{array}{c}\text { GEODEPHAGA, } \\
\left\{\begin{array}{l}\text { Maxillæ apice articulatæ. } \\
\text { Maxillæ haud apice articulatæ. }\end{array}\right.\end{array}$ & $\begin{array}{l}\text { Familiae. } \\
\text { 1. Cicindelida } \\
\text { 2. Carabide }\end{array}$ & 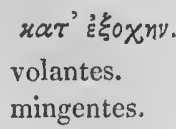 \\
\hline 2. Aberrant groupe. & $\left\{\begin{array}{c}\text { Elytra haud truncata abdomine haud pe- } \\
\text { dunculato. }\end{array}\right.$ & 3. Harpalida & currentes. \\
\hline Tibiæ anticæ emarginatæ. & $\left\{\begin{array}{l}\text { Elytra haud truncata abdomine pedunculato. } \\
\text { Elytra truncata abdomine haud pedunculato. }\end{array}\right.$ & $\begin{array}{l}\text { 4. Scaritide } \\
\text { 5. Brachinide }\end{array}$ & $\begin{array}{l}\text { fodientes. } \\
\text { crepitantes. }\end{array}$ \\
\hline
\end{tabular}

The Adephaga T'errestria of Clairville having attracted the attention of all the most celebrated of modern Eirtomologists, and having been much more studied than any other groupe of insects whatever, it is singular that so little should have hitherto been done towards their natural arrangement. M. Latreille, even in the very first number of the work which he and Baron Dejean have commenced on the Coleopteres de l'Europie, abandons the hope of effecting a natural arrangement. When I therefore attempt to combat this difficulty in the above rough sketch, it is because it becomes necessary, in order that my readers may form an adequate notion of $\mathrm{Dr}$. Horsfield's acquisitions in this brancli of natural history. 'The five families I have given above answer, witl very little variation, to the Abdominales, Cicindeleta, Truncatipennes, Bipartiti and Thoracici of Latreille: who, however, seems to be little more aware of their mutual connexion than he is of the groupe Chilopodomorpha. The above names, indeed, used by him, I do not adopt, because, in the first place, they disturb that harmony of nomenclature which is so essential to the interests of Eutomology; and, secondly, because they appear fanciful, and do not sufficiently express the characters of the respective families. I have thus thonght proper to name them from the most renrarkable or best known genus in each. M. Latreille has another family called Sululipalpes, composed solely of his old genus Bembidion, and of which the principal distinctive character is the subulate form of the last joint of the maxillary palpi, as if there were not insects in almost every adephagous family which possess this character. The family of Subulipalpes is therefore clearly to be abolished, and we sliall find that the natural place of Bembidion is in one of the five families above laid dorvi.

On examining the five families in the above table, we find the stirps returning into itself and being thus a natural groupe; for it is easy to perceive that Elaphrus has a connexion both with the Cicindelides and Carabida, that Panagaus and Licinus lead us from these last to the IIarpalide, that Acinopus and Cephalotes lead us from these by means of the genus Aristus to the Scaritide, that Siagona conducts us from the Scarilidic to the Brachinidee, from which by means of Anthia and Manticora we return to the Cicindclide. That parallel analogies exist in these families, cannot be doubted by any one who cunsiders the genera Colliuris, Agra, Dischyrius, Stomis and Cychrus, or Megacephala, Anthia, Scariles, Chlconius and Carabus, or Cicindela, Graphipterus, Siagona, Blcthisa, and Nebria, \&c. \&c. The genus Enceladus seens also to connect the opposite points of the circle of affinity, by connecting the Carabida with the Scaritida. 
In the further investigation of these families, which I shall now enter upon, I must regret my inability, for the present, to separate the genera from the subgenera with any certainty.

\section{Fam. 1. CICINDELID瓜.}

Of this family I shall offer the following Synopsis Generum, both because the number of known genera is so small, and because MM. Latreille and Dejean seem to consider it almost impossible to express by one tabular view the affinities which exist in the group. It must however be premised, that if we judge Cicindela campestris to be the type of the extensive genus Cicindela we find $C$. gracilis Pall. and C. coarctata Dej., leaving it for the genus Ctenostoma of Klug (Caris of Fischer), while by means of Euprosopus 4. notatus Lat. we approximate to Megacephala.

\section{SYNOPSIS GENERUM COGNITORUM.}

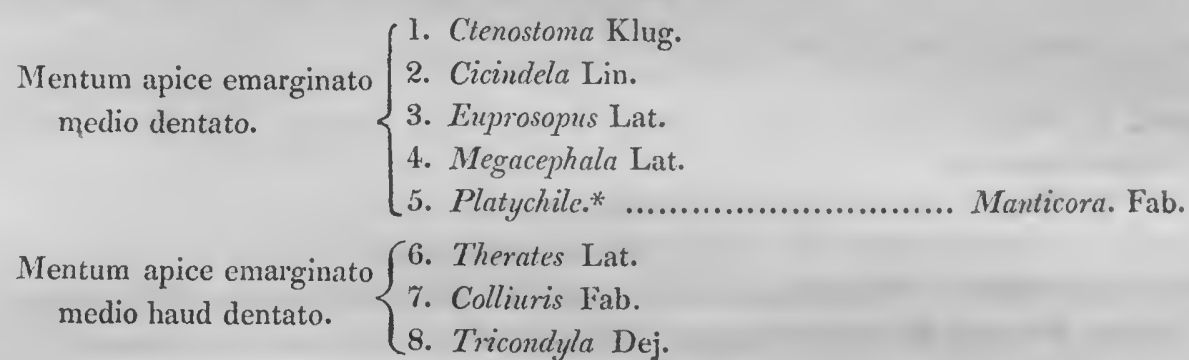

By recollecting the approximation of the extremities of this series, we have all the Cicindelide with long cylindrical bodies placed together. M. Latreille founds his primary division of the Cicindelides on the comparative length of the penultimate joint of their palpi : a consideration so vague, that we can scarcely be surprised that he should, as he says, lave found it impossible to arrange them according to their affinities. The above distribution of the family has, however, the advantage of combining all the considerations upon which the two arrangemeuts given in the "Coleoptères d'Europe" are founded, and nevertheless, avoids the glaring inconsistency of separating

* Genus PlatyChil E Nobis, Manticona Fab.

Antennce cylindricæ, articulo tertio secundo fere triplo longiore.

Labrum transversum, medio anticé bidentato.

Mandibulce exsertæ, arcuatæ, tridentatæ, dentibus apice nigris.

Palpi maxillares articulo ultimo obconico crassiore præcedente breviore.

Palpi labiales articulis duobus primis brevissinis, penultimo longo fere cylindrico, ultimo securiformi.

Mentum emarginatum medio unidentatum.

Caput magnum planum. Thorax planus in medio canaliculatus, angulo postico utrinque porrecto subspinoso. Abdomen insecti dimidii longitudine, sessile, cordiforme, thorace latius, elytris supra convexis haud connatis tectum. Pedes anteriores, in maribus saltem, tarsorum articulis tribus primis dilatatis, quarto brevissimo processuque laterali, ultimo telui unguibus acutis. Tibice omnes apice spinosæ.

PALLIDA. P. lavis tota pallida capite bipunctato clytris sub lente variolosis: variolarum centro eminente.

Manticora pallida? Fab. Syst. Eleuth. 1.p. 167.

Habitat ad Caput bonæ spei. Mus. Macleay.

Obs. This curious insect connecting Manticora with Megacephala, only differs from the Manticora pallida of

Fabricius in not having connate elytra. 
separating Ctenostoma from the long-necked Cicindelidlo, as the first does; or of placing Ctenostoma near Therates, as in the second. It is a curions proof of the value of the table given in Horæ Entomologicæ, pt. 1. p. 4, that an arrangement may thus be found, which will keep together the insects of a similar formation of palpi, and which may nevertheless not be grounded on the consideration of these organs.

The voracious insects which compose this family are all extremely active in their perfect state, and inhabit sandy districts, as it is in the sand that the artful and wary larva dig cylindrical pitfalls for their prey.

I shall now proceed to the description of such species of this most natural family as Dr. Horsfield collected in Java. 'They all belong to the three genera Colliuris, Therates, and $C_{i-}$ cindela, and eight out of fourteen of them are quite new. The length of their body, as well as that of the other insects described in this work, is always measured in inches or parts of an inch.

\section{Genus. COLLIURIS Fab.}

1. DIARDI. C. carulea antemis clavatis: clavổ cinerco-fuscâ, femoribus mufis tibiis tarsisque cyaneis, his albopubescentibus.

C. Diardi. Lat. \& Dej. Col. d'Europe, p. 67.

\section{Long. corp. $\frac{5}{8}$}

Caput labro quadrato septemfido, dentibus xqualibus, mediis obtusis, lateralibus acutis. Palpi articulo ultimo obconico apice subtruncato. Antenna breves filiformes clavâ sex-articulatâ. Thorax nec abruptè constrictus nec transversè striatus. Elytra apice truncata fere lævia.

2. EMarginata. C. cernlea thorace subvilloso, antennarum articulis tertio quarto quintoque mcdio rufis sex ultimi. cinereo-fuscis.

C. longicollis. Lat. Gen. Crust. \& Ins. t. 1. tab. 6. fig. 8.

Long. corp. fere $\frac{7}{\mathrm{~T}}$

Caput labro subsemicirculari septemfido, dentibus æequalibus subacutis. Palpi articulis ultimis obconicis abruptè truncatis apice securiformi. Antennce mediæ filiformes vix clavatæ. Thorax haud abrupte constrictus vel transverse striatus. Elytra apice dentibus acutis. Pedes femoribus rufis, tibiis tarsisque cyaneis, his, posticis præsertim, albo pubescentibus.

3. TUBERCULATA. C. carulea thorace bis abrupte constricto, antennarum articulis tertio quartoque apice rufis quinque ultimis cinereofuscis.

Long. corp. $\frac{n}{16}$

Caput labro subsemicirculari septemfido. Palpi articulis ultimis obconicis apice rotundatis. Antennet vix clavatæ longæ filiformes. Thorax constrictionc anteriore arctissimâ et sic fere tuberculatus. Pedes postici femoribus ferrugineis, tibiis cyaneis apice ferrugineis, tarsorumque articulis cinereis villosis, duobus ultimis nigris.

4. ARNOLDT. C. viridicarulea thorace transversè substriato antennis haud clavatis pallidis: articulo primo subcyaneo.

Long. corp. $\frac{21}{10}$

Caput Jabro subsemicirculari, dente laterali minuto reliquis æequalibus. Palpi pallidi articulis ultimis ovatis. Antennce longissima filiformes. Thorax fere glaber haud abruptè constrictus. Elytra apice suturâ maculâque mediâ ferrugineis. Pedes pallidi tibiis posticis ferrugineis; apice tarsisque albis.

M.S. Josephi Arnold, M.D. natura indagatoris peritissimi.

5. HoRSFIELDIY. 
5. HoRSFIELDIY. C. carulea thorace transversè striato antennis haud clatatis: axticulis tertio et quarto: apice, reliquis basi pallidis.

Long. corp. $\frac{11}{36}+$

Caput labro semicirculari septemfido, dente laterali minore reliquis requalibus. Palpi articulis pallidis apice nigris; ultimis ovatis. Antennce longissimæ filiformes. Thorax haud abruptè constrictus. Pedes postici femoribus rufis, tibiis cyaneis apice albis, tarsorumque articulis prinis albis sed penultimo ad apicem ultimoque nigris.

\section{Genus THERATES. Lat. EvRyculLE Bon.}

6. HUMERALIS. T. atroviridis aners, elytris punctatis basi plicatis testaceis apice bispinosis pedibus testaceis.

Long. corp. $\frac{3}{8}+$

Caput atroviride nitidissimum lævissimum oculis magnis nigris ; labro testaceo octofido, dente laterali distincto majore reliquis æqualibus. Mandibulce nigræ. Palpi testacei. Antenna nigræ basi testacex. Thorax atroviridis nitidissimus lævissimus subcylindricus subcanaliculatus antice posticeque constrictus. Elytra atroviridia nitidissima basi testacea plicâ depressâ suturâ nigrâ, apice dehiscentia bidentata, dente apicali majore acuto nigro. Corpus subtus nigrum ano rufo. Pedes testacei tarsorum articulis ultimis nigris.

OBs. MM. Latreille and Dejean have figured two other Javanese species of this genus, which they name cremlea and spinipennis. $T$. humeralis seems to come between the two ; but is evidently most closely allied to $T$. spiniponnis. The genus itself undoubtedly approaches to Cicindela in affinity.

\section{Genus CICINDELA.}

7. VERSTCOLOR. C. atrocceruleus thorace bis constricto elytris atris, apice violaceis; margine maculis tribus viridicneis.

\section{Long. corp. $\frac{5}{18}+$}

Insectum nitidum generi præcedenti proximum. Caput atrocæruleum rugis striatum fronte depresso oculis magnis prominentibus. Labrum viride. Mandibulce testaceæ apice nigræ. Palpi testacei articulis duobus ultimis viridibus. Antenne nigræ basi cæruleæ. Thorax tuERatis latere posticéque viridis. Elytra trimaculata maculis viridibus marginalibus; humerali elongatâ posticé latiore, mediâ transversâ, posticâque triangulari. Corpus subtus cæruleum. Pedes atrocærulei.

8. QuAdrIPUNCTATA. C. cyanea nitida labro lineâ mediâ albidâ, elytris punctis duobus pone medium niveis. C. 4-punctata. Fab. Syst. Eleuth. vol. 1. p. 239.

Long. corp. $\frac{7}{16}$

9. ANALIS. C. anea, clytris punctatis: margine cyaneo, antennis fuscis, ano pedibusque rufis.

C. analis. Fab. Syst. Eleuth. vol. 1. p. 236.

Long. corp. $\frac{\pi}{2}+$

10. HeteromaLL.4. C. subcylindrica cuprea, elytris punctis albis; tribus marginalibus aliâque parvâ mediâ.

Long. corp. $\frac{7}{16}+$

Caput cupreum rugis striatum, facie viridi ; labro carinato cupreo, apice quinque-dentato nigro. Palpi pallidi articulis duobus ultimis nigris. Antenne nigræ basi cupreæ. Thorax rugis striatus cupreus cylindricus antice vix constrictus, lateribus lineâque transversá posticâ viridibus. Elytra punctata cuprea suturâ 
elevatâ maculis quatuor, humerali minimâ, mediarum duarum marginali majore posticâque triangulari. Corpus subtus atrocæruleum. Pedes femoribus tibiisque subpiceis.

11. SEMIVITTATA. C. atra, thoracis margine pectoreque aureis, elytris vittâ submarginali abbreviatâ punctisque quinque albis.

C. semivittata. Fab. Syst. Eleuth. vol. 1. p. $23 \%$.

Long. corp. $\frac{1}{2}$

12. AURULENTA. C. cyaneo auroque variegata, elytris punctis quatuor albis : intermedio lunato.

C. aurulenta. Fab. Syst. Eleuth. vol. 1. p. 239.

Long. corp. $\frac{5}{8}$

13. FUNEREA. C. atrôcuprea elytris punctis tribus marginalibus primo humerali lunuláque apicis claratâ albis. Long. corp. $\frac{7}{16}$

Caput post oculos rugosulum punctis duobus subviolaceis. Labrum nigrum. Palpi atrocuprei apice cærulei. Antennce nigræ basi cupreæ stipite aureo. Thorax canaliculatus lineis duobus transversis. Scutellum violaceum. Elytra punctata. Corpus subtus atrocæruleum lateribus pectoris aureis. Pedes femoribus cupreis, geniculis tibiarum apice tarsisque atrocæruleis.

14. TREMEBUNDA. C. olivacea-subcenea, elytris margine laterali interrupto lunulâ humerali clavatâ apicalique dentatẩ strigâque mediâ recurvâ clavatâ.

Long. corp.-fere $\frac{3}{8}$

Species C. trisignatce DEJ. affinitate proxima. Caput cupreo-æneum rugis striatum, labro albo palpisque testaceis articulo ultimo viridi. Antenno nigra basi cuprex stipite aurco. Thorax cupreo-æneus canaliculatus lineis duobus transversis, lateribus pilosulis. Elytra subpunctata punctis vix elevatis strigâ mediâ incumbente et clavâ fere separatâ. Corpus subtus viridiæneum, lateribus pilis albis hirsutis. P'edes viridiænei albo-hirsutuli, femoribus cupreis.

\section{Fam. 2. CARABID厓.}

The collection does not contain any insect very near the type of this family, the character per cxcellentian of which, is to have the maxillie without any articulated unguis at the apex, and the anterior tibiae without any emargination on their inner side. In receding from the genus Carclbus, which is the type of the groupe, and advancing to meet the Harpalida, the first appearance of the tibial emargination mey be traced at the apex by an oblique linear canal in some insects, which nevertheless truly belong to the family. This canal, howerer, in some cases, does not advance so far as the anterior face of the tibia.

When irritated, this family of insects possesses, in a remarkable degree, the property of spirting out from the anus an excedingly acrid and volatile fluid.

\section{Genus. PANAG屃US Fab.}

15. CEREUS. P. niger clypeo glabro, occipite thoraceque profunde punctatis, elytris striis punctatis maculisque duabus undatis melleis : anticâ latiori marginali.

\& Long corp. $\frac{1}{2}+$

Caput punctis scabriusculum clypeo labroque glabris. Thorax suborbicularis punctis profundis scabriusculis. Scutellum minimum triangulare. Elytra striis decem impressis punctatis, scutellari brevis-

simâ; 
simâ ; maculisque duabus cereo-flavis, anticâ subhumerali a quintâ striâ ad marginem et posticâ versus apicem a quintâ striâ ad nonam undulatis. Corpus subtus atronitidum. Pedes nigri.

Subgenus LISSAUCheniUS Nobis. Panagaus Wiedemann? Carabus Fab.

Labrum transversum antice haud emarginatum.

Mandibulce acutæ, sinistrâ majore.

Palpi maxillares elongati articulo quarto obconico apice truncato.

Palpi labiales articulo ultimo magno securiformi.

Mentum dente sinûs simplice.

Subgenus P'anagao certe affine. Collum distinctum. Os acutum. Thorax canaliculatus marginatus nitidus subquadratus utrinque rotundatus antice posticeque angulatus. Corpus alatum. Tarsi maris antici articulis tribus dilatatis.

Ons. This genus differs from Panagaus in having the labrum not emarginate, the last joint of the maxillary palpi not triangular, the middle tooth of the mentum simple and the thorax neither suborbiculate or entire, and scarcely wider than the head. The antennæ are mutilated in the only specimen of the genus which Dr. Horsfield has brought to England.

16. RUTFEYMoratr's. L. ater capite thoraceque viridianeis, elytris sulcatis punctatis maculâ posticâ flavâ.

ô Long. corp. $\frac{7}{16}$

Caput læve labro palpis antennisque nigris, his basi subpiceis. Thorax punctatus ovatus anticé posticéque truncatus lateribus marginatis. Elytra convexiuscula atronitida striâ primâ ad scutellum brevissimâ. Corpus subtus nigrum. Pedes nigri femoribus rufis.

Oвs. This insect comes very near to the description of Carubus posticus in Fabricius, the only difference being that the latter insect has the "thorax lavis" and the "pedes fulvi." The Panagaus chalcocephalus of Wiedemann, which is also a Javanese insect, may possibly belong to the same subgenus.

\section{Fam. 3. HARPALIDF.}

We know comparatively so little of the exotic species of this most numerous family, that it is impossible for me at present to give its natural distribution with any degree of certainty. This is, indeed, my only apology for the want of regularity, which the Entomologist cannot fail to discover in the order of the following genera, which, moreover, I am quite unable to distinguish from the subgenera. The inability to separate genera from subgenera, is the unavoidable consequence of not knowing the natural distribution of the family.

\section{Genus CHLæNIUS Bon.}

17. CrNctUs. C. capite thoraceque subaneis elytris atroviridibus: margine testaceo pedibus testaceis corpore nigro.

C. Cinct us Fab. Ent. Syst. 1. p. 138.-61.

C. Xanthocrus Wiedemann, Zoologisches Magazin. Band. 2. st. 1. p. 68.

\& Long. corp. vix $\frac{5}{8}$

Caput vix thorace angustius cupreum læviusculum, facie viridiæneâ, labro testaceo, mandibulisque piceis. Antennce testacex. Palpi testacei articulo ultimo haud truncato. Thorax marginatus punctulatus. 
Elytra striata striâ primâ ad scutellum brevissimâ. Corpus subtus atronitidum abdominis margine testaceo.

OBs. This appears to be the Carabus cinctus of Fabricius, but is not the Carabus cinctus of Olivier, which is European, and has had a new specific name given to it by Duftschmidt. The true $C$. cinctus above described seems to be found throughout India, for there is not sufficicnt difference in Wiedemann's description of his $C$. Xanthocrus to separate it from our insect.

18. ApICALIS. C. niger capitis thoracisque lateribus cupreis, elytris obscuro-nigris maculâ apicali pedibusque favis. Long. corp. fere $\frac{11}{16}$

Caput thorace paulo augustius labro palpis antennisque piceis. Thorax marginatus posticè punctatus. Elytra striatâ striâ primâ ad scutellum brevissimâ.

19. QUADRICOLOR. C. niger capite thoraceque cupreis, clytris obscuris ore anternis pedibusque rufis. Carabus 4-color. Fab. Syst. Eleuth. vol. 1. p. 180. Oliv. Ins. 35. tab. 10. fig. 111.

đ Long. corp. $\frac{5}{8}$

Ors. The only difference that appenr's between the unique specimen in Dr. Horsfield's collection, and the description of Fabricius is, that the latter's insect has the head and thorax viridianeous instead of cupreous. From his $C$. tenui-collis, our insect differs in having a rounded, instead of a narrow thorax.

20. MICANs. C. elytris auro micantibus, apice maculâ testaceấ, pedibus rufis.

Carabus micans Fab. Ent. Syst. 1. 151. 115.

Carabus analis Oliv. Ins. 35 t. 10. fig. 115.

$$
\text { 子 Long. corp. } \frac{1}{15}
$$

OBs. Althongh Olivier gives Senegal as the habitat of his C. anutis, it nevertheless seems to be the same with the $C$. micans of Fabricius and our insect. If Olivier's species should prove different, it is, at least, clear that he has not sufficiently characterized it.

21. FlavigutTatus. C. capite thoraceque viridiceneis elytris obscuro-nigris striis quartâ quintâque ante maculam transversam interruptis.

Long. corp. $\frac{1}{2}$

Caput viridiæneum labro mandibulisque nigris, palpis antennisque nigro-piceis his basi illis apice testaceis. Thorax subquadratus marginatus lateribus convexis punctatus subcupreus margine viridiæneo. Elytra atra obscura punctulata striata striâ primâ ad scutellum brevissimâ, quartâ et quintâ mediointerruptis et ante maculam posticam marginalem subcruciatam flavam confluentibus. Corpus subtus atro-nitidum. Pedes femoribus flavis geniculis tibiisque nigris, tarsis piceis.

\section{Gemus CATASCOPUS-Kirby.}

Antenne articnlis secundo et tertio fere requalibus.

Labrum oblongonquadratum arcuatum, anticè angustius et profunde emarginatum, lobis rotundatis singulo setis tribus instructo.

Mandibula edentulæ acutæe crassa breves incurva. 
Palpi breves crassi articulo ultimo ovato apice subtruncato.

Labium obconicum convexum setis terminalibus instructum. Paraglossc labio duplo longiores magnæ rotundatæ.

Mentum dente medio vix conspicuo.

Caput laud thorace latius. Thorax convexiusculus truncatus obcordatus anticé latior lateribus sinuatis. Elytra margine postico unidentato convexiuscula lateribus parallelis.

OBs. Mr. Kirby has published so excellent a description of this genus in the 14th vol. of the Liunean Transactions, that the above generic character may appear superfluous ; and, indeed, it is only here given for the purpose of comparing the species more rcadily with the following geuns Pericalus, to which they approach very near in affiuity. Both genera have their elytra priemorsotruncate at the postcrior margiu.

22. ELEGAN. C. viridiaureus labro mandibulis palpis antennis pedibusque nigris, elytris sulcato-striatis striis lateralibus punctatis latere aureo.

C. elegans. Fab. Syst. Eleuth. 1.p. 184. 76.

Elaphrus elegans Weber Obs. Ent. p. 45.

Tachys elegans Schön. Syn. Ins. 1. p. 221.

Long. corp. $\frac{5}{8}$

Caput pone oculos nigros punctatum collo lævi. Thorax lineâ anticâ transversâ curvâ aliâque mediâ longitudinali fossulâque utrinque posticâ impressus. Scutellum nigrun. Elytra marginata lateribus aureis striâ scutellari brevissimâ. Corpus subtus atronitidum.

Ors. Fabricius takes no notice of the emargination at the apex of the elytra, which is : character of the genus. The Carabus elegans of Olivier belongs to quite auother genus.

23. QUADRIMACULATUS. C. viridiaurens labro palpis antennisque piceis, pedibus rufis, elytris striatis; maculis duabus favis.

Long. corp. $\frac{1}{4}$

OBs. This last species differs in several important respects from Catuscopus eleguns, which comes nearer to the species described by Mr. Kirby, and named by him C. Ifardwickii. The Carabus splendidulus of Fabricius, also belongs to the genus which thus contains four described species.

\section{Subgenus PERICALUS Nobis.}

Anteinee articulo tertio elongato.

Labrum oblongum distinctum antice emargiuatınn.

Mandibulce porrectæ subparallelæ.

Palpi mandibulis vix longiores tenues cylindrici.

Mentum bidentatum medio plano truncato.

Caput thorace latius collo distincto. Oculi globosi valde prominuli. Thorax depressinsculus obcordatus profundé canaliculatus, antice emarginatus angulis subportectis acntis, antice latior lateribus sinuatis subreflexis. Elytra marginata postice unidentata. Abrlomen depressiusculum antice angustius. 
Ors. This genus is in some respect or other connected with Sphodrus, as may be seen on examining the elongate mandibulæ, cylindrical palpi, long third joint of the antennæ, und obcordate form of the thorax. The specimen in the collection of the East India Company being unique, I an unable to give more than external characters.

24. CICINDELOIDES. P. cyaneus facie labro pedibusque nigris antennis piceis elytris striatis.

Long. corp. fere $\frac{7}{16}$

Caput pone oculos rugis striatum collo glaberrimo. Mandibula nigræ. Palpi ferruginei. Antenna apice pubescentes. Thorax lateribus rugosulis, lineâ posticâ transversâ impressus. Elytra fere sulcata sulco scutellari brevissimo et ad apicem pilis paucis raris longis instructa. Corpus subtus atronitidum. Pedes trochantere ferrugineo.

\section{Genus REMBUS Lat.}

Oвs. The synopsis of the family of Carabiques given in the work of MM. Latreille and Dejean, ought to be consulted for the characters of this genus. It is, however, easily to be known by the decp semicircular emargination of its short transverse labrum. It scems to come near both to Licinus and Badister; from the former it differs in having the three tarsi of the anterior feet less dilated in the males, and from the latter in the labrum, mentum, and palpi.

25. Polıtus. $R$. ater nitidus labro antennanumque articulis basalibus nigro-piceis; his apice pubescentibus pallidioribus.

Carabus politus Fab. Syst. Eleuth. vol. 1. p. 189.

Carabus indicus Herbst. Arch. p. 163. n. 21. p. 29. fig. 11.

\section{o Long. corp. $\frac{5}{8} t$}

Ors. The specific character given to this insect by Fabricius is so vague, that 1 have deemed it necessary to make a new one as above.

\section{Subgenus DIROTUS Nobis.}

Antennce versus apicem pubescentes, stipite minimo globoso, articulo primo obconico crassiore tertio æquali sed secundo duplo longiore, articulis ultimis æqualibus filiformibus apicali subulato.

Labrum quadratum, antice sex setis ciliatum, vix emarginatum, angulis subacutis.

Mandibule acutissimæ porrectæ attenuatæ apice arcuatæ basi vix unidentatæ.

Maxilla longa tenues falcifornes compressæ, latere interno spinis brevibus acutis armato, angulo basali setis armato; processu dorsali articulo basali longo tenuissimo, secundo pracedente fere triplo breviore cylindrico.

Palpi maxillares articulo stipitali minimo, secundo crasso subovato, tertio tenuissimo vix obconico præcedentibus simul sumptis longiore, ultimo subconico breviore.

Palpi labiales articulo primo crasso subcyliudrico brevi, secundo brevissimo globoso, tertio præcedentibus simul sumptis fere duplo longiore tenui obconico, ultimo subobconico breviore apice obtuso.

G.abium subquadratum apice truncato setis duabus terminalibus. Paraglossa utrinque membranacea 
membranacea, tenuis, cylindrica vel potius subulata, labio multo longiorc.

Mentum tridertatum dente sinus simplice.

Thorax longior quam latior, convexus, marginatus, medio canaliculatus.

Ons. This subgenus has the habit of Dolichus, from which it is not far in affinity.

26. SUbIRIDESCENS. D. atronitidus palpis antennis tarsisque piceo-rufis, thorace brevissimo, elytris striatis atroiridescentibus.

Long. corp. $\frac{3}{8}+$

Caput totum lævissimum. Elytra striâ primâ ad scutellum brevissimâ, sculpturâ marginali îrregulari. Corpus subtus atronitidum pedibus nigris.

\section{Sinlogenus COLPODES Nobis.}

Antenne articulo tertio elongato seu duorum primorum simul sumptorum longitudine; articulis tribus primis nitidis, reliquis pubescentibus.

Labrum transversum quadratum integrum.

Mandibula elongatæ trigonæ, apice acutæ incurva.

Palpi maxillares articulo tertio tenui obconico, quarto requali cylindrico-ovali vix truncato.

Mentum sinu simplice.

Caput fere longitudine thoracis. Thorax obcordatns, antice emarginatus, postice truncatus, lateribus rotundatis haud sinuatis, marginibus subreflexis. Corpus convexiusculum elytris striatis posticè sub-emarginatis. Pedes antici o tarsorım articulis omnibus dilatatis, penultimo bilobato lobo anteriore majore.

Oвs. This subgenus has some counexion with the genera Sphodrus and Anchomenus; from the former it may easily be distinguished by its thorax; and from the latter by its antennæ. The posterior sinuation of the elytra seems to indicate a relation to Catascopus.

27. BRUNNEUS. C. atrobrunneus concolor nitidus ore ferrngineo, antennis apice rubris, geniculis tarsisque piceis. Long. corp. $\frac{1}{2}+$

Caput læve facie mediâ elevatâ lateribusque rugosulis. Antennce articulis ultimis octo rubris pubescentibus apice ciliatis. Thorax lineâ anticâ transversâ, mediâ longitudinali, fossulâque utrinque posticầ impressus. Elytra striâ suturali brevissimâ.

\section{Subgenus OMASEUS Zieg.}

OBs. The following species differs from the type of the subgenus which, according to German catalogues, is the Carabus melanarius of Illiger, or C. leucophthalmus of Fubricius, in having the last joint of the maxillary palpi securiform. I do not, however, think it necessary to separate it generically from that insect.

28. VIRIDICOLLIS. O. niger capite viridi: clypeo oreque nigris, thoraceviridi: margine nigro, elytris atropurpureis के Long. corp. $1 \frac{1}{16}$ 


\section{Subgenus CATADROMUS Nobis.}

Antenna setaceæ articulis septem ultimis pubescentibus, articulo tertio præcedentibus simul sumptis breviore.

Labrum breve, latum, transversum, antice subemarginatum, medio quatuor setis instructo, angulis rotundatis.

Mandihula validissimæ capite paulo breviores, subtrigonæ, extus convexæ intus concavæ, basi unidentatæ, apice acutissimæ iıcurvæ.

Maxilla subtrigonæ intus setis ciliatæe, apice ungue acuto armato; processus dorsalis articulo basilari obconico, apicali subcylindrico incurvo vix subulato.

P'alpi maxillares articulo stipitali brevissimo ovato, secundo et tertio æequalibus hoc obconico illo incurvo subcylindrico apice subcrassiore, articulo quarto vel apicali breviore obconico apice obtuso.

Palpi labiales quasi mento affixi, stipite minimo tuberculiformi, articulis primo subobconico et secundo subgloboso quasi articulum unum albo-annulatum versus apicem constrictım formantibus, articulo tertio obconico intus setis duabus instructo, articulo ultimo breviore setâ unâ instructo, obconico, apice obtuso.

Labium stipite occulto, obconicum lateribus subsinuatis, margine antico emarginato, angulis setis duabus terminalibus instructis. Paraglossa vix labii longitudine, utrinque distinctæ, membranaceæ, tenues, subclavatæ, apice obtusæ.

Mcntum tridentatum dente sinus simplice acuto.

Elytra apice sinuata vel potius emarginata. $\delta$ Tarsi anteriores articulis tribus dilatatis.

OBs. This subgenus differs from Omaseus in having the elytra emarginate at the apex and the middle tooth of the mentum simple instead of emarginate. It approaches also to Platysma nigra in affinity, and has some relation to Cephalotes Bon. (Broscus Panz); but this is much less remarkable than the former affinity.

29. T.ENERRIOIDES. C. atronitidus viridi-marginatus elytris sulcatis : sulco a suturâ secundo bipunctấo margineque viridi-punctato.

Carabus tenebrïaides. Oliv. Ins. N0. 35, p. 17.8.

Long. corp. $2 \frac{1}{2}$

OBs. This insect, of which a wretched figure is given by Olivier, is the largest and handsomest of the Javanese Adephaga. A piceous variety in my father's collection is the very specimen from which Olivier took his description and figure. Its identity, therefore, with the above species is completely ascertained, and its nigropiceous colour in all probability merely results from its having been a young insect when taken.

\section{Genus DICÆLINDUS Nobis.}

Antenna setaceæ thorace longiores articulis primo et tertio æqualibus, ultimis octo pubescentibus.

Labrum transversum quadratum. 
Mandibulce ut in Diccelo.

Palpi muxillares articulo penultimo et ultimo æequalibus, hoc eylindrico ovali.

Mentum dente sinus bifido.

'Thorax transverso-quadratus lateribus rotundatis marginatis, antice emarginatus, postice truncatus, medio canaliculatus, fossula lineari utrinque postice impressus.

Corpus valde depressum elytris striâtis. Pedes antici maris tarsorum articulis duobus dilatatis.

OBs. The affinities of this genus would be rery difficult to discover were it not for a Brazil insect, which I believe forms M. Latreille's genus Microcephalus, ${ }^{*}$ and which clearly connects it with Dicalus. This Brazilian insect has the subquadrate mentum of Diccelindus, and the securiform palpi of Dicalus. It may also be worth while to compare our insect with Amaru and Dinodes.

30. FELSPATICUS. D. nigro-iridescens laevissimus labro antennis tarsisque piceis, elytris septemstriatis : margine exarato postice subcatenulato.

Long. corp. $\frac{1}{16}$

Caput atronitidum, postice subiridescens, facie bifossulatâ, labro quadrato piceo. Antennce articulis basalibus nitidis piceis, reliquis pubescentibus rufis. Thorax politissimus iridescens. Scutellum minutissimum. Elytra sicut Felspath politissima. Abdomen subiridescens. Pedes nigri tarsis ferrugineis.

* In protesting against the slovenly mode lately adoptcd by some continental naturalists, of publishing generic names without defining the genera to which thcy are applied, I must express my regret at seeing it now resorted to by those who have most powerfully appealed against it. Because they are themselves well acquainted with the insects to which they assign certain names, they fancy that others must also know them, forgetting that the general adoption of the name must always depend on the accurate definition of the relation which exists between it and the insect. At least $I$ hope, that it is this species of oversight which alone occasions the grievous inconveniences of which Entomology has to complain; for I can scarcely suppose that naturalists, to whom the science owes so much in other respects, would condescend to confuse it, or thwart its progress for the mere sake of securing, by a doubtful priority, so trifing an advantage as a generic name, and so miserable a fame as must depend upon such priority. Certain it is, however, that inextricable confusion must arise from this course of proceeding, unless it be now at once firmly rcsisted; and unles: Entomologists resolve to abide by the maxims laid down on this subject by Linnæus and Fabricius. Procceding on the principles laid down by these great authorities, who have both declared characters absolutely necessary, in order that genera may be known, I am sure that the reader will consider me justified in considering no name as secure, unless it be accompanied with a character. In thcse pages all names of mere catalogues, whether generic or specific, shall be as much overlooked as if they never had existed. In some few cases, perhaps where the names like Rembus, Omaseus, are assigned to described insects, and the meaning of the author is thus, in some measure, ascertained, I may choose not to increase thc confusion by refusing to adopt them, although M. Latreille has most truly said, that even such names without characters, "ne sont que de simples indications et $n$ 'imposent aucune loi."

I ought here to observe, on my own part, that it may possibly be found that M. Wiedemann has published in the pages of his Zoologisches Magazin, some few of the species here described; and of course, his names in such cases must be adopted as having the right of priority. Although I have long becn in expectation of receiving the work complete, I unfortunately, at present, only possess some loose sheets of it, which I owe to the kindness of Dr. Escholtz. In every instance, however, where I could obtain M. Wiedemann's names, I have carefully adopted them, for his descriptions are not only detailed, but very accurate. 


\section{Genus TRECHUS Clairv.}

31. ConveXUs. T. atronitidus pedibus antennisque piceis, his ad basin palpisque pallidioribus, elytris substriatis. Long. corp. $\frac{1}{8}$

Insectum Cephalotis habitu parvulum alatum vix huic generi associandum. Caput nigronitidum latitudine thoracis. Antenne articulis subæqualibus primo duobus sequentibus simul sumptis breviore, articulis quatuor ultimis crassioribus, apicali longiore ovato. Palpi maxillares articulo ultimo subulato cum tertio breviore quasi articulum unum fusiformem formante. Thorax convexus marginatus obcordato-truncatus, basi angustior, latior quam longus, medio vix canaliculato. Elytra striis sub lente distinctis, primâ ad scutellum brevissimâ.

OBS. Although I have assigned this little insect to the genus Trechus, I am aware that it differs from it in many respects. The only specimen however in the collection is so mutilated, that I cannot venture to found a subgeuus upon it, and therefore present as full a description of it as its being pasted down on paper will permit me to make. It agrees with the characters of Trechus given in the Rigne Animal of M. Cuvier; but these have been too vaguely drawn up to enable a beginner to form a correct idea of the genus.

\section{Subgenus GNATHAPHANUS Nobis.}

Antenna articulis fere aqualibus secundo breviori.

Labrum transverso-quadratum, angulis anticis rotundatis.

$M$ andibula sub clypeo fere occultæe; sinistrâ ad basin solum apparente.

Palpi maxillares articulo ultimo subsubulato, tertio obconico breviori.

Palpi labiales articulo ultimo præcedente breviore, subulato, acuto.

Mentum breve, transversum, dente sinus minimo simplice.

Caput transverso-quadratum, latius quam longum, antice truncatum facie brevissimá. Thorax ut in Harpalo, sed fossula lineari brevi utrinque postice impressus. Corpus oblongum. Elytra striis irregularibus punctisque discalibus, apice emarginata vel excisa.

Ors. To this subgenus the IIarpalus Thunbergi, of Scliöntserr appears to belong. It differs, hwwever, from the following species, in being pubescent.

32. VULNERIPENNIS. G. ater, elytris decem-striatis: striâ secundâ brevi spatioque inter strias tertiam et quartam septem penctalo.

Long. corp. $\frac{1}{16}+$

Insectum nitidiusculum. Caput lineâ transversâ anticâ utrinque fossulatâ. Palpi articulo ultimo piceo. Antennce obscuræ pubescentes. Thorax lateribus posticeque marginatus, medio canaliculatus. Scutellum inconspicuum. Elytra marginata striâ secundâ cum prinıâ ad scutellum confluente; striis quartâ et quintâ, sextâ et septimâ apice confluentibus, spatio inter septimam et octavam bi-vel-tripunctato, illoque inter deciman et striam marginalem punctato scabroso. Pedes nigri.

\section{Fienus HARPALUS Lit.}

33. Punctilabris. H. niger antennis apice rufo-pubescentibus, labri limbo antico brunneo sexpunctato, facie transversè-lineatâ. 
Caput lineâ transversâ angulis deflexis. Thorax lævissimus marginatus margine subrugosulo, lineâ mediâ longitudinali, fossulâque utrinque postice inconspicuâ. Elytra striata striâ secundâ ad scutellum brevi.

Ons. The following description of an insect unique in the collection is taken from so mutilated a specimen, that although I am almost sure it is not a true Harpalus, I cannot venture to assigu it to any other subgenus. Although it has a punctured thorax the habit is rather that of Gnathaj hunus than of Ophomus Dej.

34. PUnctulatus. H. niger, totus subtilissime punctulatus, elytris pubescentibus striatis, pedibus favis tarsisque piceis.

Long. corp. $\frac{5}{16}$

Caput labro transverso quadrato subemarginato.

\section{Sulhgenus AMARA Bun.}

35. TRICOLOR. A. nigra elytris aneis, labro nigro, palpis antennis pedibusque ferrugineis.

Long. corp. $\frac{3}{8}$

Caput lineâ faciali transversâ utrinque fossulatâ. Thorax convexus, marginatus, lævissimus, vix caiıaliculatus sed fossulâ postice utrinque impressus. Elytra striata striâ secundâ ad scutellum inconspicuâ. Corpus subtus nigrum.

36. SUBOLIVACEA. A. nigronitida labro femoribusque piceis, antemnis pedibusque ferrugineis, elytris ceneo-olivaceis viridibus vix nigris.

Long. corp. $\frac{3}{18}+$

Cuput nigronitidum latum transversum labro semicirculari. Thorax planus, lateribus posticeque marginatus, vix postice utrinque impressus. Elytra striata margine punctato, striâ secundâ brevi tertiaque versus apicem punctis aliquot raris.

37. SUBREEA. A. nigronitida labro piceo, antennis basi pedibusque rufis, thorace postice utrinque impresso, clytris nigro-ceneis.

Long. corp. vix. $\frac{3}{15}$

Præcedente paulo minor differt antennis basï solum rufis, thorace sulcis tribus posticé distinctis, femoribus nigris elytrisque haud viridibus.

Subgenus DIORYCHE Nobis.

Anlennce lineares, pubescentes, articulo tertio duobus græecedentibus s.s. breviore.

Labrum transrerso-quadratum angulis rotundatis.

Mandibulo breves.

Palpi maxillares articulo quarto subulato, precedente obconico breviore.

Palpi labiales articulo ultimo acuto sub-subulato.

Mentum sinu simplice angusto.

Caput facie emarginatâ. Thorax latus; punctatus, marginatus, canaliculatus, obcordatoquadratus, antice cmarginatus. Elytra striata, apice sinuata vix emarginata.

38. TORTA. D. atronitida antennis ferrugineis, pedibus favis, elytris nigro-ceneis: striistertiẩ sextâque punctatis. Long. corp. $4+$ 
Caput labro piceo palpisque ferrugineis. Thorax posticé creberrime punctatus. Elytra striâ secundâ ad scutellum brevi, spatio inter strias tertiam et quartam, quintam et sextam punctato. Coxa ferruginex.

OBs. The Caralnus favilabris of Fabricius perhaps comes near to this insect, if not to the subgenus Colpodes.

Subgenus HYPHÆREON Nobis.

Antennæe pilosulæ vel pubescentes articulo tertio secundo duplo longiore.

Labrum quadratum.

Mandibula longiusculæ acutæ.

Palpi maxillares articulo ultimo elongato tenui ohconico.

Palpi labiales articulo ultimo breviori subulato.

Mentum dente sinus simplice parvo acuto.

Caput oblongum glabrum, facie lateribus subparallelis utrinque fossulatis. Thorax lævis, nitidus, canaliculatus, subquadratus, lateribus rotundatis, antice marginatus, marginibus lateralibus subpunctatis subreflexis, posticoque subpunctato, fossulâ utrinque vix conspicuâ. Elytra striâ secundâ ad suturam brevi.

39. REFLEXUS. H. atronitidus antennis oreque piceis, pedibus obscuris; femoribus testaceis, thorace postice punctis scabroso.

Long. corp. $\frac{1}{4}+$

Caput mandibulis nigris palpisque rufis. Antennce obscuro-piceæ apice pallidiores. Elytra striis profundis. Corpus subtus atronitidum, ano obscuro.

Suitgenus HYPHARPAX Nobis.

Antennce longitudine thoracis, apice crassiores, pubescentes, articulis secundo et tertio æqualibus.

Labrum quadratum.

Mandibula longiusculæ acutæ.

Palpi maxillares articulo ultimo elongato, tenui, obconico.

Palpi labiales articulo ultimo breviori subulato.

Mentum tridentatum.

Caput triangulare inter oculos bifossulatum glabrum. Thorax brevis, convexiusculus, lavissimus, transverso-quadratus lateribus rotundatis ; lineâ mediâ longitudinali haud marginem anticum attingente fossulâque posticâ utrinque lineari. Elytra striata striis æequalibus.

40. LATERALIS. H. atronitidus ore antennis pedibusque ferrugineis, elytris striis lateralibus creberrime punctulatis apiceque ferrugineo.

Long. corp. fere $\frac{x}{4}$

Caput atronitidum labro piceo, palpis ferrugineis. Thorax postice trilineatus.

Gemus ANAULACUS Nobis.

Antennce moniliformes, crassæ, vix capite longiores, articulis secundo et tertio fere æqualibus. Labrum breve, latum, transverso-quadratum, angulis obtusis, antice vix emarginatum. Mandibula latæe trigonæ latere externo incurvo. 
Palpi maxillares articulo ultimo brevi cylindrico apice vix tenuiore.

Paraglossce distinctæ tenues cylindricæ membranaceæ.

Mentun trilobum.

Caput triangulare lævissimum inter oculos hand bifossulatum. Thorax duplo latior quam longus, antice emarginatus, postice vix convexıs, lævissimus canaliculatus. Corpus totum depressiusculum Jatum abdomine sessili. Scutellum indistinctum. Elytra submarginata. Pedes quatuor postici spinosuli.

41. SERICIPENNIS. A. atronitidus ore antennis pedibusque ferrugineis, elytris lavissimis nigrosericeis: maculis duabus rufis.

Long. corp. fere $\frac{T}{4}$

Caput atronitidum labro piceo, mandibulis palpisque ferrugineis. Thorax atronitidus lateribus pilis paucis ciliatis. Elytra atra sericea maculâ sagittiformi rufâ ad humeros alterâque securiformi ad apicem. Corpus subtus atronitidum.

OBs. This is one of those singular and apparently anomalous forms which occur not unfrequently among the Harpalida.

Subgenus גEPHNDIUS Nobis.

Antennce capite duplo longiores, apice crassiores pubescentes moniliformes, articulo secundo et tertio æequalibus.

Labrum transverso-quadratum, antice vix emarginatum.

Mandibuloe latæ trigonæ latere externo incurvo.

Palpi maxillares articulo ultimo elongato tenuiore subsubulato.

Menti sinus simplex.

Caput triangulare lævissimum, inter oculos haud bifossulatum. Thorax marginatus, duplo latior quam longus, antice emarginatus, fere sinuatus, postice lobatus lævissimus canaliculatus utrinque postice vix fossulatus. Corpus totum depressiusculum oblongum abdomine pediculato. Elytra submarginata striata striâ prima scutellari brevi indistinctâ. Pedes quatuor postici spinosuli.

42. ADELIOIDES. RE. atronitidus labro pedibusque nigro-piceis, antennis palpisque ferrugineis, elytris holosericeis atris.

Long. corp. $\frac{\frac{1}{4}}{4}$

Subgenus C⿸ELOSTOMUS Nobis.

Antennce articulis ultimis novem pubescentibus, subæqualibus, secundo breviore.

Labrum tranversum, ad basin latius, margine antico pubescente emarginato sex setis distinctis, lobis rotundatis.

Mandibulce subinæquales crassæ arcuatæ, apice obtusæ, crenatæ, sub labro latentes.

Palpi brevissimi ; maxillares articulo ultimo longo subulato acuto.

Labium minimum, paraglossis fere duplo longioribus laminam membranaceam subquadratam, antice bilobatam, basi augustiorem formantibus.

Mentum in ore concavo deflexum, dente sinus minimo acuto vix conspicuo. 
Caput lævissimum facie subemarginatû. Thorax circuli segmentum majus formans, marginatus, convexus haud canaliculatus, suborbicularis, margine antico truncato lineâque transver'sâ inpresso. Elytra apice subsinuata, striata, striâ primâ ad scutellum brevissimâ.

OBs. The affinity of this subgenus seems to be towards Licinus and Badister.

43. PICIPES. C. atronitidus antennis obscuris : articulis duobus primis pallidioribus, pedibus pallido-piceis, elytris apice subpiceis.

Long. corp. vix $\frac{\pi}{4}$

Caput lævissimum labro nigro, mandibulis corporeque subtus nigropiceis.

\section{Fam. 4. SCARITID AE.}

The typical character of this family, which appears more numerous in the new world than in the old, consists in the broken antennæ, the pedunculated abdomen, the semilunar thorax, and digitated anterior feet.

MM. Latreille and Dejean, in their late work, Coleoptères d'Europe, seem to regard the scaritide as animals not carnivorous. But against this opinion, so contrary to what might have been judged from analogy, we have the authority of two accurate observers, MM. Oliviet and Lefebre de Cerisy. The latter naturalist, who, from his residence at Toulon, possesses many facilities for studying their economy, has marle some most interesting observations on the Genus Scarites, and particularly the S. Gigas of Olivier. He finds them to be nocturnal insects of prey. During the dlay, they lurk almost without motion in the holes which they dig in the earth, but at night they sally out and prey on the various Melolonthide, \&c. which may happen to fall in their way.

The only three species of the family which Dr. Horsfield found in Java belong all to the typical part of it.

\section{Genus CLIVINA Lat.}

44. SabULOSA. C. nigro-brunnea capite lineâ anticâ transversali: vertice haud impresso, elytronum striis fere crenatis.

\section{Long. corp. $\frac{1}{4}+$}

Insectum Clivinâ arenariâ Lat. angustius, corpore minus convexo. Caput frontis medio haud puncto impresso. Thorax lateribus truncatís vel saltem quam in C. Arenaria haud tam convexis.

\section{Genus SCARITES Fal.}

45. SEMTCIRCULARIS. S. mandibulis canaliculatis, thorace postice rotundato, elytris punctato-striatis : striâ tertiá unipunctatâ.

An Scarites punctum, Wiedemann, Zool. Mag. Band 2. s. 1.p. 38 ?

Long. corp. fere $\frac{x}{2}$.

Insectum totum atronitidum. Caput vix bisulcatum sed lateribus striatis. Thorax lævissimus, marginatus, canali medio lineam anticam transversalem impressam attingente haud ultra progrediente. Elytra marginata striis punctatis impressis punctoque striæ a suturâ tertiæ versus apicem impresso. 
ANNULOSA JAVANICA.

OBs. This species, if not a variety of a Bengal insect described by Wiedemann under the name of S. punctum, comes exceedingly near it.

46. INDUs. S. mandibulis substriatis, thorace postice subtruncato, elytris lineato-striatis striâ tertiâ bipunctatâ. Scarites indus Oliv. Ins. 2. no. 36. tab. 1. fig. 2.

Long. corp. $\frac{11}{18}$

Insectum S. subterraneo $\mathrm{F}_{A B}$. affine, totum nigronitidum. Caput sulcis duobus rugosulis impressum. Thorax levissimus marginatus, canali medio lineam anticam transversalem impressam attingente haud ultra progrediente. Elytra marginata striis impressis; striâ a suturâ tertiâ punctis duobus mediis hoc apicem versus illo basin versus impressâ.

Ors. This species was confounded by Fabricius with his $S$. subterraneus, an American insect, which would have been an Attelabus with Degeer.

Fam. 5. BRACHINID E.

In this family, as well as in the last, we have rarely, if ever, that dilatation of the tarsal joints, which often marks in so extraordinary a manner the difference of sex among the Harpalidce and Carabida.

The typical insects of the family are gregarious, and well known for the detonating mode of defence which they employ against their enemies. This curious property results from the rapid volatilization when exposed to the air of an acrid liquid analogous to that which we have already noticed in the Carabide, but which in the Carabida retains its liquill state on being ejected fron the anus. The construction of the two sacs whicl secrete this fluid is explained by Cuvier in the Rigne Animal.

Each of the three first insects to be described in this family might have been assigned to new subgenera, as they do not accurately coincide with Bonelli's characters for the genera Dromius, Lamprias and Lebia; but as their place in the system is visible at first sight, I have judged it unnecessary to multiply subgeneric names.

\section{Genus DROMIUS Bon.}

47. Tetraspilotus. D. nitidus, capite nigro, thorace nigropiceo, elytris atris striatis : maculis duabus favis.

Long. corp. vix s

Caput nigrum labro oblongo quadrato antennis palpisque piceis. Thorax obcordatus latior quam longus depressiusculus canaliculatus lateribus subreflexis, Elytra maculis duabus hac basali illâ posticali. Corpus subtus pedesque picei.

OBs. This species has the middle tooth of the mentum indistinct, and thus to a certain degree leaves Dromius. Carabus notulatus, of Fabricius, appears to come near to our insect, which, with the following species, has the elytra very little truncated, if at all.

\section{Genus LAMPRIAS Bon.}

4.8. RUFICEPS. L. rufa nitida, elytris cyaneis striatis medio depressiusculis: striis profundioribus, oculis geniculisque nigris.

$$
\text { Long. corp. } \frac{5}{16}
$$

OEs. This species appears to be more common on the continent of India than in Java. 
Gemus LEBIA Lat.

49. SPLENDIDULA. L. rufa, oculis albis, thorace marginato, elytris striatis viridiceneo-marginatis apice truncatis.

An Lebia marginalis, Wiedemann Zool. Mag. Band. 2. s. 1. p. 60 ?

Long. corp. $\frac{3}{10}$

Insectum umnino splendidulum corpore subangusto. Caput rufum clypeo inter antennas fossulato, labro magno quadrato, mandibulis latis inermibus apice acutis. Mentum lobis latis sed maxillarum basin haud tegentibus. Antennce articulo tertio brevissimo. Thorax truncato-obcordatus rufus medio canaliculato. Scutellum inconspicuum rufum. Elyira abbreviata abrupté truncata pulcherrima. Corpus subtus nitidissimum rufum. Pedes rufi.

OBs. This species cones so near to a Bengal insect described by Wiedemann as L. marginulis, that I must leave the separation of them to the entomologist who may have it in his power to examine both.

Antenne breves crassiusculæ.

\section{Subgenus ORTHOGONIUS Dej.}

Labrum transverso-quadratum, antice cmarginatum lobis rotundatis, singulo setis tribus anticc instructo.

Mandibula inæquales, subtrigonæ, latæ, superne convexæ, angulatæ, subtus concavæ, basi subdenticulatæ, apice acutissimæ incurvæ.

Maxilla sinuatæ apice latiores, latere interno membranaceo ciliato haud spinuloso vel setoso, processu dorsali articulo ultimo oblongo tenui ovato vel fusiformi; dorso pone palpos duobus tuberculis setigeris instructo.

Palpi maxillares articulo primo brevissimo, secundo maximo crasso obconico subincurvo, tertio obconico, quarto conico, his duobns quasi articulum unum oblongum ovatum formantibus, ultimo tertio breviore.

Palpi labiales articulo basilari (labii stipiti affixo) brevissimo lato, articulo secundo brevi ubconico vix subgloboso, tertio obconico præcedentibus simul sumptis longiore, quarto præcedente breviore subcunico vel potius subulato.

Labium angustum subcylindricum apice clavatum setis duabus instructum. Paraglossce labio haud longiores latæ angulis rotundatis membranaceis; Stipes labii magnus semicircularis menti sinum fere implens.

Mentum sinu edentulo setâ utrinque instructo angulisque acutis.

Caput facie anticâ setis sex instructâ. Pedes unguibus subtus denticulatis tarsorumque articulo penultimo bilobato.

OBs. As M. Dejean has assigned a name to this subgenus in a manuscript catalogue, I have thought proper to adopt it, although the genus is now for the first time characterized. It agrees with the three former genera in having the ungues of the tarsi denticulated beneath, and the elytra subtruncated at the apex; but in most other respects of external appearance it differs widely from the Brachinida in general. It has the habit of a Nebria, and possibly approaches to this genus or to Blethisa in affinity. Judging from the ciliated membranaceous maxillæ, I suspect that this genus is not very carnivorous in its habits. 
50. PICILABRIS. O. nigro-brunneus capite nigro, thorace sulco transverso postice impresso, clytris striis subpunctatis.

Long. corp $\frac{5}{3}+$

Caput nigrum labro palpisque piceis. Antenna piccæ, apice pilosulæ obscuræ. Thorax canaliculatus antice haud marginatus, duplo latior quam longus, lateribus subreflexis, quadrâ mediâ impressâ, angulis fossulatis. Elytra striâ secundâ ad scutellum brevi. Corpus subtus piceum. Pedes picei tibiis nigris.

51. BRUNNILABRIS. O. Ununneus capite thoracis disco elytronumque limbo nigris, thorace anchorâ dorsali impressâ margineque pallido, elytris striato-punctatis.

Long. corp. fere $\frac{11}{16}$

Caput labro palpis antcnnisque brunncis, his apicc obscuris hirsutis. Thorax canaliculatus, duplo latior quam longus, fossulâ utrinque postice impressus. Elytra striâ primâ et secundâ ad scutcllum brevi confluentibus. Corpus subtus brunneum. Pedes nigriusculi femoribus brunncis.

52. Alternans. O. niger thorace sulco transverso postice impresso, elytris striis vix geminatis, interstitiis alteruitim punctulatis.

Plochionus alternans, Wiedcmann, Zool. Mag. Band. 11. s. 1. p.52.

Long. corp. $\frac{5}{8}+$

Caput palpis brunneis labro antennisque nigris, his apicc pubcscentibus. Thorax antice marginatus canaliculatus duplo latior quam longus, fossulâ utrinque posticc impressus. Elytra striâ sccundâ ad sentcllum brevi cum primâ confluente. Corpus subtus nigro-brunneum pedibus nigris.

OBs. The above-mentioned three species come very near to the genus Plochionus of Dejean, and accordingly Wiedemann appear's to lave referred all the species of the genus Orthogonius with which he was acquainted, to Plochionus, viz. his $P$. duplicatus, $P$. acrogonus, and $P$. alternans. Plochionus, however, has a more western geographical situation, no species being, to my knowledge, found farther east than Bordeaux, while America appears the metropolis of the genus. Some species of the genus Plochionus may be expected to occur in the south of England or Ireland, particularly the P.Bonsfilsii of Dejean.

\section{Genus DRYPTA Fab.}

53. LINEOLA. D. rufa elytris punctato-striatis pubescentibus : vittâ media rufâ, pedibus rufo-testaceis ; geniculis piceis.

An Drypta lineola, Meg. apud Dej. Catal. p. 2.?

\section{Long. corp. $\frac{3}{16}$}

Caput rufum convexum punctatum oculis albis, mandibulis maxillisque apice piceis, palporum maxillarium ruforum articulo ultimo ovato. Antennce rufe articulo secundo Jongissimo apicc piceo. Thorax punctatus subcylindricus laud capite longior, truncato-obcordatus, postice marginatus, medio canaliculatus. Elytra apice vix truncata nigra, striis decem, scutellari brevissimâ, vittâque mcdiâ longitudinali rufâ haud basin sed suturam ad apicem attingente. Abdomen subtus atro-viride.

OBs. This species varies, or at least the $D$. lineola which comes from the continent of India is so neal to it, that it is scarcely possible to assign distinct specific characters to them. A New Holland Drypta, which I have named "Austrulis," differs also from the above only in 
having the palpi, antennæ and feet black, the coxæ and base of the femora being rufotestaceous.

54. UNIDENTATA. D. cyaneus fernoribus sanguineis, elytris postice unidentatis : decem striis punctorum interstitiisque punctatis.

Long. corp. is

Caput cæruleum punctatum oculis albis, nıandibulis piceis, palpis maxillaribus longissimis rufis articulo ultimo ovali sericeo-albicante. Antenne rufie articulo basilari conspicuo, secundo ad apicem quartoque ad basin piceis. Thorax capite multo longior punctatus subcylindricus medio haud canaliculatus. Elytra apice abrupte truncata vel unidentata pubescentia. Corpus subtus nigro-cyaneum. Pedes coxis testaceis, femoribus rufis, geniculis tibiisque piceis, tarsis rufescentibus.

Ors. In Bn. Dejean's catalogue we find a manuscript-name "longicollis" assigned without any description by Megerle to an Indian Drypta. As I conceive this entomologist may only have obtained a knowledge of such Indian insects as were collected by M. Fichtel, I account his D. longicollis, although the name will equally apply to the above Javanese insect, to be a native of the Continent. Drypta longicollis differs in that case from $D$. wnidentata, in being atrocyaneous with yellow femora, in having truncated but not dentated elytra, and in having the fourth joint of the antennæ altogether rufous. Drypta flavipes of Wiedemann, a Bengal insect, seems to be still another distinct species.

Subgenus APTINUS Bon.

55. OccIPITALIS. A. alatws ater capite flavo : vertice nigro, thorace bimaculato, elytris sulcatis favo bimaculatis. d Long. corp. $\frac{3}{4}$

A. bimaculato $\mathrm{LAT}_{\mathrm{A}}$. et $A$. fulminanti $\mathrm{F}_{\mathrm{AB}}$. affinis sed alatus. Caput flavescens postice punctatum maculâ mediâ nigrâ campanulatâ. Antennce flavescentes articulo basilari nigro. Thorax niger marginatus subcanaliculatus maculâ utrinque ferrugineâ. Elytra atra sulcis haud striulatis striis elevatis ad apicem pallidis, maculâ humerali rotundâ strigâque mediâ abbreviatâ flexuosâ clavatâ transversâ valde angulatâ flavis. Corpus nigrum. Pedes flavi geniculis nigris.

Ors. Bonelli has separated the genus Brachinus from Aptinus, on no other account than that the latter is apterous. If, however, we reckon B. sclopeta Fab. to be the type of one genus, and $B$. hallista, Ill. of the other, the insect above described, although winged, will come nearer to the latter than to the former. The fact is, that Aptinus has not yet been properly separated from Brachinus.

M. Dejean appears to be acquainted with other Javanese species of the genus than the one mentioned above.

Genus PLANETES Nobis. HELLUo Dej.

Antennce articulo primo et quarto aqualibus et hoc secundo tertioque simul sumptis longiore.

Labrum quadratum antice vix emarginatum.

Palpi maxillares articulo secundo duobus ultimis simul sumptis requali, tertio obconico, quarto oblongo crasso apice obtuso.

Palpi labiales articulo ultimo securiformi sed vix tertio crassiore.

Mentum tridentatum. 
Caput ut in genere Taro CLAIRv. Thorax subquadratus canaliculatus postice angustior angulis anticis rotundatis. Corpus valde depressum.

Oвs. This genus is intermediate between Tarus Clairv. (Cymindis Lat.) and Helluo, Bon.; from the latter it differs in the labrum not being acuminate, and from the former in the shape of the maxillary palpi and thorax.

56. Brmaculatus. P. ater labro palpis antennis pedibus elytrorumque maculâ mediâ ferrugineis elytris sulcatostriatis.

Long. corp. $\frac{1}{2}$

Caput atronitidum transversé punctatum facie lævi bipunctatâ antice truncatà. Thorax atronitidus punctatus. Elytra atra depressiuscula sulcata, sulcis profunde striatis maculâ versus basin ovali ferrugineâ. Corpus subtus atrum.

Ons. This species may perhaps be found too near the Carabus Stigma of Fabricius, but certainly is not the same with the Helluo distactus of Escholtz, described as a Javanese insect in Wiedemann's Zoological Magazine; although I suspect the latter to be also a Planetes, from what Dr. Escholtz says of the thorax being proportionally longer than in his Helluo impictus, a species found in Bengal. Helluo distactus, differs from Planetes bimaculatus in being striated and having each stria marked with two rows of points. None of these species, however, are true Helliones, and the mistake has arisen from the continental entomologists being so little acquainted with the original Helluo of Bonelli, Helluo costatus, which is a New Holland insect.

\section{Stirps. 2. HYDRADEPHAGA. HYDRocanthaRI Lat.}

In the Geodephaga the binary subdivision of the grompe is not very distinct, because the characteristic marks of each subdivision insensibly pass into each other. In this stirps of aquatic carnivorous insects it is however different, for the binary subdivision is remarkably distinct, and I know as yet of no insect which can satisfactorily fill up the hiatus that occurs between the Gyrini of Linnæus and his Dytisci.

The larvæ of the Hydradephaga differ from those of Geodephaga in being truly aquatic, and therefore breathing by tracheal branchiæ. Their prothorax also, or that segment of the body which corresponds with what is usually called the thorax of the perfect insect, is not of is more corneous texture than the other segments.

I shall not at present attempt to divide the Hydradephaga into families, but content myself with giving the following approximation to a natural arrangement. The genus Hoplitus of Clairville seems to form the type of a family which I have not here ventured to designate.

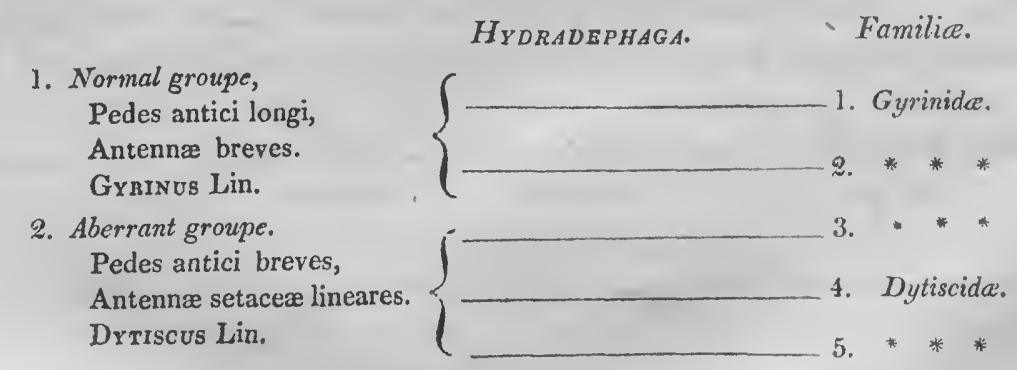

Fam. 


\section{Fam. 1. GYRINID E.}

Degeer, in his immortal work, has observed, "Les Tourniquets approchent beaucoup des Scarabés-d'cau ou des Dytisques;" but the remark was neglected by Latreille until lately. In his Genera Crustaceorum et Insectorum he placed the Gyrini and Parni in the same family, named by him Otiophori, thus confounding a relation of analogy with one of affinity.

I know not whether I am quite right in considering these insects as belonging to the normal groupe of Hydradephaga; but certainly, both in their perfect and larva form, they are farther distant from the Carali than Dytiscus. As however it is imposible to proceed naturally in a linear series of description, I begin with this Hydradephagous family, which is known to every entomologist by its gregarious sportive nature and its auriform antennæ.

The larvæ of Gyrinide are exactly Scolopendrce in appearance, the tracheal branchia answering to the false fect of the Chilopoda. The perfect insects are almost the only Hydraecphaga that possess a metallic lustre.

Genus DINEUTUS Nobis. GYRINUS Lat.

Antenna brevissimæ apice subacutæ.

Labrum semicirculare haud ciliatum.

Pulpi clavati.

Pedes antici fere corporis longitudine.

Oiss. These few character's, although merely external, will sufficiently separate this grenus from Gyrinus. M. Latreille has observed that, the exterior biarticulated lobe of the maxilla, $o r^{\prime}$ (as it is more commonly called) the internal maxillary palpus becomes evanescent in the exotic Gyrini, as well as in certain exotic genera of Geodephaga such as Therates.

57. PoLtTUs, D. nigro-ceneus lavissimus, clypeo nigro-piceo angulis rugosulis aureis, pedibus anticis piceis posticis pallidis.

$$
\text { Long. corp. } \frac{3}{4}
$$

\section{Genus GYRINUS.}

58. DrNTIPENNIS, G. niger vix ceneus elytris postice unidentatis apice truncato-sinuatis punctulatis substriatis.

\section{Long. corp. $\frac{5}{16}+$}

Labrum nigrum. Corpus subtus nigro-æneum vix cupreum ano hirsuto. Pedes antici picei posticis quatuor rufis.

Ors. I am uncertain whether this species be sufficiently distinct from the Gyrinus Indus of thic supplement to the Ent. Syst, a species which Fabricius afterwards abandoned in the Syst. Eleutheratorum.

59. Lrмbarus. G. elytris apice truncato-sinuatis striatis ad suturam aneis, vittâ mediâ sub-cupreâ margineque viridi.

Long. corp. vix. $\frac{5}{18}$.

Caput viride vertice subcupreo labrique margine viridi. के Caput punctis duobus sub-impressis.

Fam. 


\section{Fam. 4, DYTISCID Æ.}

The larvæ of these insects have not the lateral branchial appendages of the Gyrinide, and are therefore much less scolopendriform. Indeed their sub-convex and rather conical body with various other circumstances might, on a first view of them, make us place them out of their natural situation; but their obvious analogy to the larvæ of Hemerobii, as well as to the larvæ of Geodephaga, will serve to make them known to the practical entomologist.

There are few insects so voracious as the Dytiscida, and their power of moving at will either' in the water, in the air, or on the earth, gives them ample means of satisfying their rapacity.

I may in this place make the remark, that aquatic insects do not among themselves differ $=0$ much in form as terrestrial insects. It is not merely that they are ferver in species, and therefore may be expected to form fewer genera, but that the tropical genera of aquatic insects are much the same with our own, or at least are not so different from each other as the tropical and European Geodephaga. Another remark to be made is, that aquatic insects are in general as large or larger with us than they are within the tropics. I know of no Hydrophilida larger than our Hydrophilus piceus; and the largest of the Dytiscida, that has ever come under my notice, is the D. latissimus of Sweden. The only exception to this remark among the Hydrudephagu occurs in the Gyrinida, as for instance in the genus Dineutus above described.

\section{Genus COLYMBETES Clairv.}

60. OCTODECLM-MACULATA. C. niger capite maculis tribus, thorace marginali, elytris vittâ marginali maculisque novem favis.

Long. corp. $\frac{5}{16}$

Caput maculis tribus mediis Thoraxque maculâ marginali flavis. Elytra striis tribus punctorum obsoletissimorum, vittâ marginali nec basin nec apicem attingente, maculis flavis tribus basalibus, quatuor mediis fasciam fere formantibus et duabus apicalibus. Corpus subtus nigrum abdominis lateribus rufo-maculatis. Pedes quatuor antici flavi.

61. FABRICII. C. collo nigro, thorace rufo, elytris cinereo-rufoque striatis.

Dytiscus varius. Fab. Syst. Eleuth. i. p. 267, 48.

Long. corp. $\frac{3}{8}$

Oвs. Fabricius described an insect in the Ent. Syst. which he found in the Banksian cabinet, and called it $D$. varius. Afterwards he confounded a Sumatra insect, which he found in Daldor $\mathrm{ff}^{\mathrm{s}} \mathrm{s}$ cabinet, with his $D$. varius, and altered the original specific character to suit his new insect, which I here call $\boldsymbol{D}$. Fabricii.

62. SUTURALIS. C. elytris cinereo-nigroque variegatis: striis tribus punctorum impressis suturâ nigrâ lineâque utrinque rubrâ.

Long. corp. $\frac{1}{2}$

Caput obscure ferrugineum punctis duobus impressis medio utrinque nigrum, ore palpis antennisque testaceis. Thorax glaber lævis marginatus subcanaliculatus rufus maculâ mediû transversali nigrâ. Elytra punctis numerosissimis approximatis nigris cinereisque variegatis, striis punctorum obsoletis, margine exteriore rubro. Corpus subtus nigrum, pedibus quatuor anticis femoribusque posticis piceis.

63. VITTATU. 
63. VITTatus. C. ater laevis elytris vittâ sub-marginali flavâ: maculâ baseos atrâ.

Dytiscus vittatus, Fab. Ent. Syst. i. 19014.

Oliv. Ins. 40. tab. i. fig. 5 .

Long. corp. $\frac{1}{2}$

Ons. The black spot on the yellow vitta in this species varies exceedingly.

64. FAs:1 4TUIs. C. elytris flavis : fasciis duabus suturâ punctoque apicis nigris.

Dytiscus fascictus. Fab. Ent. Syst. 1. 189, 9.

Oliv. Ins. 40, tab. 2, fig. 19.

Long. corp. $\frac{1}{2}+$

Genus DYTISCUS. Liı.

65. GRTSEUS. D. cinereus thorace punctis duoljus nigris elytris fasciâ dentatâ nigrâ.

Dytiscus griseus, Fab. Ent. Syst. 1, 191, 16.

Oliv. Ins. 40. tab. 2, fig. 12.

Long. corp. $\frac{1}{2}+$

OBs. This species appears to be very generally dispersed over the warmer latitudes, as it oecurs in my father's collection from Bengal, Bombay, Italy, Spain, France, and even from the Island of St. Bartholomew, in the West Indies, where it was collected by Dr. Forstrom. This West Indian specimen only differs from the rest in wanting the black spots on the thorax, which spots are also evanescent in European varieties of D.griseus.

66. RUGosus. D. nigro-viridis, clypeo thoracisque margine laterali favis, elytris medio rugosulis vittâ marginali interruptâ.

$$
\text { Long. corp. } 1_{16}^{3} \text {. }
$$

Caput atrum clypeo labroque flavis antennis palpisque pallidis. Thorax nitidus striis duabus lateralibus aliâque anteriori transversà leviter punctulatis. Elytra nigra limbo lævissimo nitido, striis tribus punctulatis exaratis, vittâ marginali flavâ postice fractâ apicem elytrorum haud attingente. Corpus piceum lateribus pedibusque anticis pallidis.

67. Limвatus. D. olivaceus thoracis elytrorumque margine flavo, abdomine atro: maculis lateralibus testaceis.

Dytiscus limbatus. Fab. Syst. Eleuth. 1, p. 258, 2.

Dytiscus aciculatus. Oliv. Ins. 13, 6. tab. 3, f. 30.

Long. 1 공

Stirps. 3. PHILHYDRIDA.

Entonılogists in generai, with the exception of M. Latreille and his follower's, have allowed a close affinity to exist between this stirps and the Hydradephaga, and nothing but the difficulty of making this affinity accord with the other parts of his system could ever have inade so acutc an entomologist as M. Latreille to doubt so obvious a truth. Originally both these stirpes were known under the common denomination of Hydrocanthari, and Linnæus comprized all the species under the generic name of Dytiscus, separating the groupe into two sections, which correspond with our stirpes Hydradephaga and Philhydrida. To these sections, in process of entomological investigation, he gave the names of Dytiscus and Hydrous, but finally for this last groupe adopted the word Hydrophilus, which had been already appropriated to them by Geof- 
froy. Still, however, the Dytisci and Hydrophili were kept close to each other as neighbouring groupes by Linnæus, Geoffroy, Fabricius, and Olivier, until M. Latreille thought proper to separate then.

Olivier seems to have well remarked that Degeer's opinion as to the number of joints in the antcnnæ of Hydrophilus picens being only nine, is founded rather on appearance than on truth, and that the real number corresponds with that of the Dytisci, namely eleven, the only difference being that the eighth and tenth joints are here very minute. Their place is marked by the distances which intervene between what are commonly considered the second and third, and the third and last joints of the clava. The fact however is, that the number of joints in the antenna is in these two stirpes subject to some variation from the typical number, which in Coleoptera is eleven.

I have already alluded to those two divisions of the maxilla in Hydrophilus of which one corresponds with what is usually termed the internal maxillary palpus in Adephaga, although it now ceases to be palpiform. In some genera however, such as Spercheus, which come nearest to the Hydradephaga, the outer process of the maxilla is long, slender, and truly palpiform. Fabricius accordingly, when he instituted the genus Spercheus assigned six palpi to it, as well as to Dytiscus. The feet, indeed, of the Philhydrida, as well as other points of their external anatomy, their larvæ and their halsits, all prove their affinity to the Hydradephaga.

The larva of Hydrophilus piceus is long and somewhat conical, and bears great resemblance to that of a Dytiscus, the body being terminated in both by two filiform processes, which seem useful for the respiration of the insect. One grand difference between them, as Lyonnet has shown in contravention of a curious fancy of M. Frisch, is that the head of the larva of Hydrophilus being adapted to its labit of preying on small mollusca as they float in the water, is inclined towards its back, whereas in the other it has its usual inclination towards the belly. Both larva are thus carnivorous, quit the water when full-grown, and having made an oval cocoon, undergo metamorphosis in the earth.

The Philhydrida appear, when arrived at their perfect state, to be in some degree herbivorous, or at least to lose in a great measure the carnivorous habits of the Hydradephaga; they seem therefore to indicate an approach towards insects truly lierbivorous. Perhaps Hydrophilus piceus is as voracious an animal as belongs to the stirps; yet we may learn how inferior it is in voracity to an Adephagous insect, from the anecdote recorded by Clairville, on the authority of Dr. Esper, who having confined an insect of this species in a glass of water with a Dytiscus marginalis, not more than half its size, soon found it yicld itself an easy prey to the latter, which having detected a vulnerable part between the head and thorax, greedily devonred it. M. Miger, also, who observed so well the singular manners of this family, and who has given so detailed an account of them in the fourteenth volume of the Annules du Musérm, ascertained that the greatest part of the food of the perfect insects is derived-from aquatic plants.

I shall offer the following arrangement of the Plilhydrida as an approximation to the natural one : 


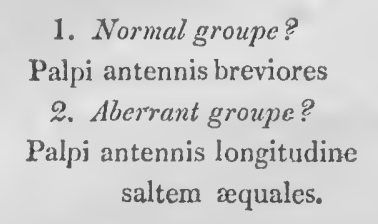

\section{PHILHYDRIDA.}

\{1. Heteroceride?

2. Parnida,

3. Helophorida.

4. Hydrophilida, (analogous to the Gyrinide.)

(analogous to the Dytiscider.)

In this table, although the aftinity of Sphceridida to Hydrophilida, and of Heteroceridce to Parnidce is incontestable, I have thought proper to mark the place of the Sphcridide and Heteroceridce with doubt, as their connection is not very distinct. The fore tibiæ, however, in both families are spinous; and the tetramerous genus Georissus seems to be of some use in uniting these discordant groupes.

\section{Fam. 1. HETEROCERIDAE.}

The type of this family is tetramerous, but its affinity to the Parnida has never been contested. Dr. Horsfield has brought no insects from Java that can be safely assigned to the groupe.

\section{Fam. 2. PARNID E. PARNIDEA. Leach.}

In the Genera Insectorum et Crustaceonum M. Latreille has placed the type of this family or the true genus Parnus in the same family with Gyrinus, and has called the whole group Otiophori. He thus mistook a very obvious relation of analogy for one of affinity; and accordingly, in the Considérations Générales and the third volume of the Règne Animal, we find that he separates Parnus and Gyrinus, giving them their proper affinities, but taking little or rather no notice of the analogy which exists between them. The genus Potamophilus of Germar (Hydera of Latreille) appears to lead off to Octhelius of Leach, and other insects of the next family.

Subgenus DRYOPS. Leach.

68. HaRDHICKIr. D. olivaceo-fuscus aut nigricans, tomentosus, elytris punctorum impressorum lineis octo tarsisque omnibus rufescentibus.

Long. corp. $\frac{x}{4}$.

- Ors. This subgenus is characterized by $\mathrm{Dr}$. Leach in the third volume of his Zoological Miscellany, page 88, and may be easily known from Parmus by its wanting the thoracic longitudinal fossulie of the latter genus. Dryops Hardwickii differs from the type and only other known species of the subgenus, (that is from D. Dumerilii, which is a South of Europe insect, ) in having a darker colour, and the points of the elytra inpressed instead of elevated. I hare named this new species after Major-General Hardwicke, a gentleman to whom every naturalist is indebted for the zeal and science he has displayed in the prosecution of the several departments of Oriental Zoology.

\section{Fam. 3. HELOPHORID $Æ$.}

There are no species of this family among Dr. Horsfield's insects. The groupe is remarkable among the Philhydrida for the metallic lustre which generally characterizes the insects which 
compose it, and which only again occurs in the contiguous family of Hydrophitidce. They appear to lead naturally to Berosus, and such other genera of the next family.

\section{Fam. 4. HYDROPHILID $\mathbb{E}$.}

The analogy between the larger insects of this family composing the genus Hydrous and the larger Dytisci is too striking to escape the notice of the most cursory observer. Their manners, their larvæ, the singular dilatation at the extremity of the anterior tarsi of their males may all serve to shew us how Linnæus came to name the type of this family Dytiscus piceus.

The most singular habit known of this insect is that the female spins out of her abdomen a gummy matter, which forms an envelope for her eggs, and these, disposed symmetrically in their oval receptacle, float about on the surface of the water until the larva are hatched. It is not known how many other genera of the family possess this curious economy.

The insects of this fanily which come from tropical climates prove, by their near affinity to European insects, how much fewer typical forms there are of aquatic insects than of terrestrial.

Subgenus BEROSUS. Leach.

69. Purchellos. B. griseo-flavescens, capite scutello thoracisque maculâ mediâ divisâa nigris, clytris striatis: maculis tribus.

Long. corp. $\frac{1}{8}$.

Insectum supra punctulatum. Elytra maculis tribus obscuris striisque nigris impressis, interstitiis crebré punctatis, punctis nigricantibus.

Oвs. 'This genus often retains some of the inetallic Iustre of the Helophoride.

Genus ENHYDRUS. Meg.

70. PALLENS. E. albicans nitidus punctulatus, thorace maculis quatuor obscuris transversé dispositis elytrisque obsoleté striatis.

Long. corp. $3^{3}$.

Genus SPERCHĒUS. Fab.

71. PLATYCEPHALUS. S. infra nigricans, supra scabriusculus cinereus, elytris lineis quatuor elevatis: dorso bituberculato, pedibus subferrugineis.

Long. corp. $352^{\circ}$

Ors. This curious little insect is truly a Spercheus, and thus becomes the second species of the genus that is known to entomologists.

Genus HYDROUS. Lin. Leach.

72. PALLIDIPALPTS. H. olivaceo-niger, elytris striis punctorum tribus, margineque vagé punctulato.

Long. corp. $1 \frac{1}{2}$.

Hoc Insectum ab alio Americano (H. FUSCIPALPE mihi) ex Insulâ Sanctæ Trinitatis simillimo differt corpore convexiore breviore, colore dilutiore, palpis crassioribus, et antennarum articulo sexto præcedentibus simul sumptis multo breviore.

73. Bilineatus. 
73. BILINEATUs. H. nigropiceus, elytris sulculis punctorum duobus obsoletis, lineâ mediâ punctorum vagorum, aliisque marginalibus.

$$
\text { Long. corp. } 1 \frac{3}{16} \text {. }
$$

Insectum præcedenti simillimum, sed differt corporis longitudine, elytrorum sculpturâ lineisque punctorum vagis marginalibus tribus vel quatuor, femoribus brunneis, articulo palporum ultimo brevi crassiore subsecuriformi.

\section{Fam. 5. SPH ERIDID E.}

It is not my intention to attempt at present the accurate determination of the natural place and boundaries of this fanily, because it would require a more minute and detailed investigation than the limits of a local Fanna will admit. The remarkably close connexion, however, which exists between M. Latreille's Hydroplitii and Sphceridiota both in construction and economy, induces me to describe in this place the only two species of Spharidium which are to be found in Dr. Horsfield's collections ; and, indeed, although I would not by any means be supposed to lay down my arrangement as certain, or for the present attempt to give more than a general statement of the near affinity which exists between this family and the last, yet $I$ cannot forbear calling the attention of the entomologist to the circumstance of the genus Sphoericlinm possessing those two processes to their maxilla, which for'm so prominent a character of the Philhydrida as a stirps.

This family is less aquatic than any of the four preceding, and I agree with Fabricius in thinking that such genera as Phalacrus, Agathidium, \&c., may safely be assigned to it. It is true that Latreille has separated them from Sphcridium, because they are tetramerous; but by parity of reasoning, since Heterocerns and Georissus are also tetramerous, he ought to have separated the first from the vicinity of Parmus and the other from that of Elmis. It is the evil, however, of half-artificial systems like that which is founded on the number of joints in the tarsi, that while they are at utter variance with natural affinities, they do not even answer the humble purposes of a catalogue.

The similarity of certain species of this family to Petalocerous insects has often been remarked, and in fact it is from these insects that a transition is made to the Clitognathornorpha or Coleoptera laving larvæ which resemble Chilognatha.

\section{Gonus SPII ERIDIUM. Fab.}

74. HYDIOPHILOIDES. S. atronitidum punctulatum, palpis antennis tarsis thoracisque lateribus nigro-rufescentibus, elytris punctorum striis impressis.

$$
\text { Long. corp. } \frac{7}{27} \text {. }
$$

Ons. This species indisputably prores the close affinity of Splloeridium to the last family.

75. MARGINATUM. S. elytris immaculatis maculisve obsoletis, thoracis elytrorumque margine externo pedibusque ferrugineo-lutescentibus.

Spharidium Scarabcooides, Var. D. Lat. Gen. Ins. et Crust. vol. ii. p. 72.

Sphceridium marginatum, Fab. Syst. Elcuth. vol. i. p. 93.

Long. corp. $\frac{5}{32}$.

OBS. Without attempting to decide the question, whether all those insects which flliger considers as varieties of Sphcridium Scarabcoides be really distinct species, I shall merely say, that the above 
above described Javanese insect will be found to differ from the European $S$. marginatum in no respect, except perhaps that of size. With respect to the general affinities of the genus $S p h a$ ridium, it may be sufficient to mention, that this insect would have been a Dermestes with Linnæus and Geoffroy, and an Hister with Degeer.

Stirps 4. NECROPHAGA. Lat.

We now come to a stirps so close in affinity to the Philhydrida, that Dumeril has combined them in one groupe, to which he has assigned the name of Helocera, from the antennæ in both being in a similar manner clavated.

The Necrophaga, however, of Latreille, as this stirps is characterized in the Genera Insectorum et Crustaceorum, vol. i. p. 239, is a most natural groupe, distinguished from the Philhydrida by their habits being less aquatic, their mouth being proninent, and mandibles generally exserted. The first joint of the maxillary palpi is also evanescent in this stirps, so that these organs may in general be described as three-jointed. Indeed it is only the Dermestider, or fifth family of the Necrophage, which retains any character of the Spheridide, and the Dermestidce are also anong the least Chilopodomorphous insects of the tribe, being closely allied to the Byrrhide, and so leading to the Chilognathomorpha. Linnæus and Geoffroy both observed the affinity existing between the Dermestide and Sphceridida, and have even described the S. scarabaoides as a Dermestes. It is fiom insects, situated between the types of these two families, that the Byrrhidce take their rise, and lead us to the tribe of insects having Chilognathiform larva or Chilognathomorpha.

Although the stirps of Necrophaga comprizes many herbivorous iusects, we find that each family composing it, has not merely a disposition to feerl on animal matter, but retains, moreover, many vestiges of the predaceous habits of the more typical insects of the tribe. Thus among the Silphida, the Silpha 4-punctata climbs the oak for the purpose of devouring the caterpillars, of which so many species infest this tree. Several other Silphe attack live terrestrial Mothusca, just as we have seen the neighbouring stirps of Philhydrida prey on certain aquatic animals of the same sub-kinglom. The disposition of many of these insects to feed on fungi, is in accord with a general remark to be made on carnivorous Coleoptera, namely, that as the aberrant insects of any groupe leave the living aninal food, which forms the entire subsistence of the normal part of tlie same groupe, they prey on dead animal matter, or, in preference to other vegetable matter, on fungi.

With respect to the affinities which connect the families of this stirps, I shall, according to my usual practice, avail myself of the argumentum ad verecundiam, in explaining them. True it is, indeed, that no naturalist has yet thought of combining tliese observations, and the consequence has been, that M. Latreille, among others, has never, in his various works, given the same arrangement of the stirps twice.

M. Latreille has shewn the affinity of the Dermestida and Scaphidida, in what perhaps is the most able of his works, I mean the Histoire Générale des Insectes, etc. vol. ix. p. 190 and 233, where he has made one family of them, and thus adopted an opinion of Degeer.

In his Considérations Générales, p. 176, as well as the IIistoire Générale, Latreille has moreover shewn the affinity of the Scaphididae to the Silphida, thus adopting an opinion of Linnæus and Geoffioy. 
In his Genera Insectorum $\epsilon$ Crustaceorum, vol. ii. p. 2 and 8, Latreille has proved the affinity of the Silphidee to the Nitidulida, thus adopting another opinion not only of Linnæus, but of Degeer and Olivier.

In the same Histoire Gérérule, and Genera Insectomom et Crustaceorum, Latreille thinks the affinity of the Nitidulides and Engidce so close, that he makes only one family of them, thus adopting an opinion of Geoffroy and Fabricius.

Finally, in the Histoire Générale, vol. x. p. 16, M. Latreille acknowledges that the Engidce have, "beaucoup de rapport avec les Dermestes," thus adopting an opinion of Linnæus, Scopoli, Geoffroy, Fabricius, and Olivier.

Now these various affinities have never yet been supposed to lead to any general consequence, and nevertheless if connected, which, as was before said, they never yet have been, they produce the following symmetrical table of the stirps :

\section{NECROPHAGA.}

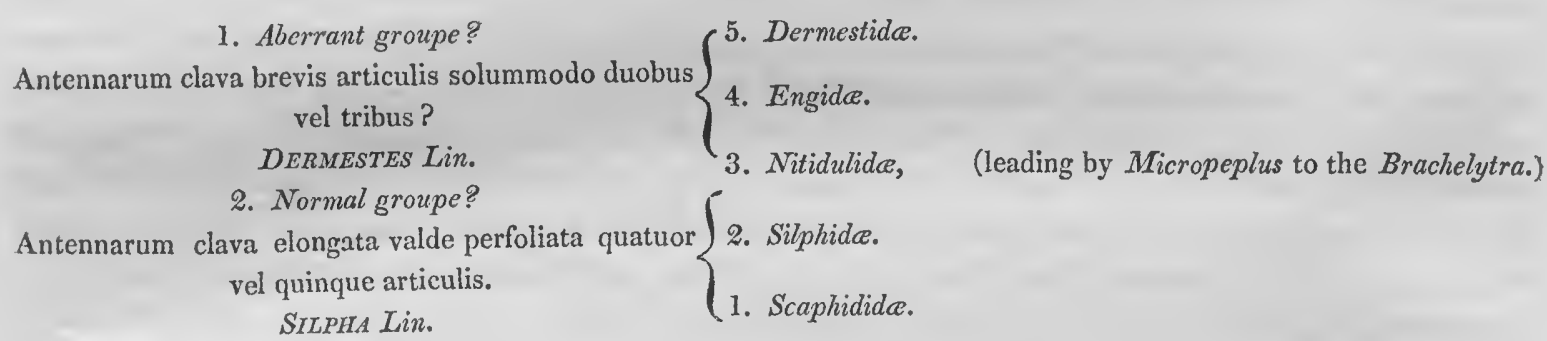

The Necrophaga thus comprize almost all those insects which Linnæus called either Dermestes or Silpha. So close indeed is the affinity of these two Linnæan genera, that of the modern genus Nitidula we find one species assigned by the Swedish naturalist to his genus Silpha, and another to his genus Dermestes.

The Nitidulide lead, by means of Cercus and Micropeplus, to the Brachelytra. That Micropeplus is an insect which leaves the typical Necrophaga, is clear from its different antennæ, and from its having beell described as a Staphylinus by so many authors.

Many, if not the greatest part, of Latreille's Taxicornes belong to this stirps, which, however, has too few Javanese species in it to induce me at present to investigate it accurately. I shall therefore now content myself with saying, that Latreille's groupe of Clavicornes, as given in the Dictionnaire d'Hist. Naturelle, is altogether artificial. It is a heterogeneous collection, that is not only inferior to all his former groupings of this family, but is even inferior to what $M$. Dumeril had already done in characterizing his Helocera.

\section{Fam. 1. SCAPHIDID $\not$.}

The first thing which strikes us in the appearance of this family is the remarkable relation of analogy which it bears to the Mordellidae, the place of which, in their own circle of affinity, is thus pointed out. Mr. Spence has, among other pertinent remarks on the genus Choleva, in the 11 th volume of the Linnzean Transactions, justly observed, that the resemblance between Mordella and Choleva is merely superficial. So also is the relation between Scaphidium and 
Ripiphorus, which last genus is not nearer in affinity to Mordella, than Scaphidium is to Choleva. M. Latreille, however, in the Regne Animal, has sufficiently proved the very obvious and close affinity of Scaphidium to Choleva, which it is rather surprising that so acute an entomologist as $\mathrm{Mr}$. Spence shonld ever have doubted. A more than sufficient recompense, however, for the above error is, that $\mathrm{Mr}$. Spence saw that Choleva had an affinity both with Dermestes and Silpha. He has also shewn the relation between it and the genus Anisotoma of Knoch, and thus proved his being no servile follower of the Tarsal system. In short, I would recommend the study of his excellent Monograph on Choleva to all who may wish to understand something of this family, which seems to be, as he observes, nore common in Europe than in the other quarters of the globe. Dr. Horsfield found none in Java.

The external process of the maxillæ in the genus Choleva, althouglı not distinctly articulated, is always linear or sublincar, and thus affords some ground for Herbst's describing one species as a Carabus, if indeed Mr. Spence be correct in suspecting him to have done this.

\section{Fam. 2. SILPHIDA.}

That Dr. Horsfield should have brought from Java none of the typical insects of this family, which are also those of the stir'ps, I attribute rather to their rarity than to there being no Silphe or Necrophori on the island. The disgusting nature of the substances in which such insects are to be found, and their peculiar lıabits, give then often an opportunity of escaping the eye of an observer, even in these temperate climes; and we can casily conceive how the same habits should give them tenfold security in tropical countries, where the putrid efluvia of dead carcases are as dangerous as offensive. That Silphce may be found in the Indian Archipelago I conclude from their being ascertained to exist in New Holland and on the continent of India.

The larvæ of Silphide possess a flat elongate body, terminated laterally by a somewhat shinp angle, and having the last segment provided with two conical appendages. They cnjoy that activity which is the general character of Chilopodiform larvæ, and know how to search out fiesh food for themselves, when they have consumed that which the parent insect had provided for them. When fully grown they bury themselves in the earth, and there undergo metamorphosis.

'The abbreviated clytra of Necrophorus mark the typical insects of the groupe, and shew the strong relation of analogy which they bcar to Creophilus, and the other corresponding genera of the coutiguous stirps of Brachelytra.

\section{Genus PELTIS. Fab. TH Y}

76. OVALIS. P. ovata castanea limbo dilutiore, thorace elytrisque punctis impressis.

$$
\text { Long. corp. } \frac{7}{24} \text {. }
$$

Insectum $P$. ferruginece Fab. quodammodo affine, at corpore minus convexo minusque oblongo. Elytra punctata lineis sex impressis punctulatis, serieque punctorum excavatorum in interstitiis disposità.

OBs. This genus has certainly an affinity to Colobicus, and possibly thercfore to Eledona. It is at the extremity of the family. 


\section{Fam. 3. NITIDULID E. NitiDULARIA Lat.}

The larva of this family resemble those of the last very closely, as may be seen on inspecting the figure of the larva of Nitidula varia Fab. (Silpha grisea Lin.) given by the late Mr. Curtis, in the second volume of the Linnæan Transactions. This larva seems to live on putrid vegetable matter.

The perfect insects of the family are to be found in almost all substances, some inhabiting flowers, and others carrion. They differ from the Silplide by their mandibles being bidentate at the apex, and in general by their anterior tarsi having the three first joints dilated. From the Engido they may be distinguished by their more peltate form and transverse thorax.

Genus NITIDULA. Fab.

7\%. Prcta. N. ovalis, fronte bipunctatâ, clypeo truncato, elytris punctulatis : striis elevatis setigeris.

Long. corp. $\frac{17}{3} \overline{2}$.

Obs. Species $N$. grisece LIN. (N. variee $\mathrm{F}_{\mathrm{AB}}$ ) simillima, at brevior et convexior. Caput ferrugineum punctulatum fronte utrinque fossulâ impressâ, clypeo antice truncato, labro emarginato. Thorax ferrugineus punctulatus pilis albis raris vestitus. Elytra nigro ferrugineoque varia.

\section{Fam. 4. ENGID E.}

'The typical insects of this family differ in general from those of the last by their elongate form, or by the semi-lunar termination of their maxillary palpi, and minuteness of the penultimate joint of their tarsi. In the genus Cryptophagus the sexes may be distinguished by a difference in the number of joints of their posterior tarsi. And if Mycetophagus, and even Triplax, belong to this family, as I suspect they, with their immediate affinities, will be found to do, then tetramerous insects belong to the stirps of $N$ ecrophaga as well as to the Philhydrida. Accurate examination, however, seems to prove that such insects are not truly tetramerous; the penultimate joint of the tarsi, which is so minute in Engis, becoming in Triplax only more evanescent. The manner in which this change is effected, becomes manifest on comparing the genera Ips, Engis, Triplax, and Erotylus. The connexion existing between these, no one can doubt, and, indeed, M. Lstreille long since remarked it. I am not lowever prepared to say, that the Erotyli fall into this tribe; but if they should eventually be proved to have this situation in nature, it will be another instance of that manifest relation which exists between the stirps of Necrophagous insects and the Linnæan genera Cassida, Chrysomela, and Coccinella. It is, perlaps, by the Erotyli that the opposite points of the circle of Colcoptera meet, for I do not think that this genus will go well among the true insects with anopluriform larvæ. As to the Erotyli being tetramerous, it is a circumstance to which little importane ought to be attached, since the five articulations of the tarsi are visible in several species, and other insects which are close to the grenus, such as Mr. Kirby's genus Spheniscus, are lieteromerous.

Plateria and its affinities seem also to have a faint relation to these insects, as well as Cerylon Sylvamus, \&c. But without estimating the degree of importance that ought to be attached to such relations, I shall not at present attempt to do more than indicate them, since the true limits of 
ANNULOSA JAVANICA.

this most difficult family must depend in a great measure on our better acquaintance with their larva. Perhaps it woukl be better for the present to consider the typical insects of the grenpe as unascertained, and the propriety therefore of the family name Engidce as at least donbtful. It is observable, however, that ail these insects were Dermestes with Linnæus and Fabricius ; and, as in another part of the work I shall have to return to this subject, in the mean time I shall merely remark, that from the Helopida this groupe may easily be distinguished by their clavate antennx.

\section{Genus DACNE Lat. ENGrs Payk.}

M. Latreille, in his Précis de Genres founded the genus Dacne on the species of insect called by Herbst, Ips humeralis; and soon after Paykull, in the Fauna Suecica, gave the generic name of Engis, with appropriate character's, to the same insect. Fabricius, in the Systema Eleutheratorum, adopted this genus with the name given to it by Paykull, and placed in it an A merican insect, the Erotylus bifasciatus of Olivier (Enc. Meth. Hist. Nat.), which insect is, however, sufficiently distinct, by its maxillary palpi having their last joint hamner-shaped, whereas the European insect (Ips humeralis of Herbst) has the same joint only obtuscly subulate. I leave, therefore, the original name of Dacne with the last-mentioned insect, and give the name of Engis to those exotic insects which coincide with Engis fasciata of Fabricius, in the above description of their palpi, anc. which differ from true Erotyli, in having the penultimate joint of thcir tarsi visible, although very small.

78. SexNotatA. D. antice angustior, nigro-nitida, thoracis angulis anticis, elytrorumque fasciis duabus transversis cruentis.

Engis sexnotata, Wiedemann Zool. Mag. 2. 1. 131.

Long corp. $\frac{3}{4}$

Caput vertice concavo antennarumque clavâ tomentosâ murinâ. Thorax antice angustior, ad angulos subproductus lunulâque cruentâ insignis, posticé vix fossulatus. Scutellum nigrum. Elytra striis punctorum obsoletis, et maculis duabus transversis undatis cruentis, anticâ dentatâ humerum versus. Corpus atronitidum. Pedes nigri tibiis ad apicem tomento brunneis.

79. QUADRIMACULA. D. nigronitida pubescens punctulata, elytris maculis transversis: humerali mediâque rufis, humero scutelloque nigris.

Engis quadrimacula, Wiedemann Zool. Mag. 2. 1. 132.

\section{Long. corp. $\frac{1}{2}$}

Antenna nigræ. Thorax niger, antice subangustior. Elytra striis punctorum obsoietis, ad scutellum nigra, maculâ humerali utrinque excisâ, mediâ lunulatâ. Corpus atronitidum. Pedes nigri tibiis ad apicem tomento brunneis.

\section{Genus ENGIS. Nobis.}

The genus Oxyporus among the Brachelytra has its labial palpi somewhat like those of this genus.

80. VERTTCALIS. E. atra; verticis maculis duabus, thoracis annulo irregulari, elytrorum fasciis duabus apiceque rubris.

$$
\text { Long. corp. } 1 \frac{3}{20}
$$

Caput nigrum, vertice ad oculos bimaculato, antennarumque clavâ tomentosâ. Thorax niger, marginatus, fossulis ad marginem posteriorem tribus minutis, annulo medio rubro ad angulos protento et lineam 
dorsalem versus obscuriori. Scutellum nigrum. Elytra nigra marginata punctorum lineis septem obsoletis, apice et fasciis dentatis tribus rufis, suturâ et fasciæ humeralis maculis dưabus nigris. Corpus oblongum aterrimum. Pedes nigri tibiis plantisque tomento brunneis.

81. ANNULATA. E. nigro-nitida, thorace postice subpunctato, elytris annulis duobus rufis, pedibus atropiceis.

Long. corp. $\frac{11}{2} \frac{1}{0}$

Caput palporum articulo maxillarium ultimo rufo antennarumque clavâ tomentosâ. Elytra lineis punctorum octo obsoletis, annulis basali et posticali rufis. Scutellum nigrum. Corpus oblongo-ellipticum.

82. CRUENTA. E. nigronitida, thorace utrinque maculâ longitudinali, elytris lunulâ basali maculâque posticâ sanguineis.

\section{Long. corp. $\frac{4}{5}$}

Caput bifossulatum. Thorax niger marginatus, fossulis tribus ad marginem posticum obsoletis, lineî utrinque longitudinali posticé subfurcatâ. Scutellum nigrum. Elytra nigra lunulâ humerali maculâque apicali rufis. Corpus oblongum aterrimum. Pedes nigri tibiis plantisque tomento brunneo.

83. LunULATA. E. nigro-nitida, thoracis maculis tribus anticis, elytrorum cruce basali lunulâque posticâ sanguineis.

$$
\text { Long. corp. } \frac{11}{20}
$$

Caput subpunctatum. Thorax maculis tribus anticis linearibus brevibus rufis. Elytra lineis punctorum obsoletis, cruce humerali vel lunulâ caudatâ humerum amplectente et lunulâ posticali simplice sanguineis. Pedes nigri tibiis plantisque tomento brunneis.

81. LitURATA. E. nigronitidla, thoracis medio maculis annulato, elytris ad apicem liturâ marginali sanguineâ.

Long. corp. $\frac{2}{2}$

Thorax maculis obscuris rufis annulum quasi in medio formantibus. Elytra lineis septem punctorum obsoletis. Scutellum nigrum. Pedes nigro-picei.

85. SUbRotUNDA. E. nigronitida, capite thoraceque subpunctatis, elytris fasciis duabus lunulatis dentatis rubris : suturâ nigrâ.

\section{Long. corp. $\frac{2}{5}$}

Elytra nigra, lineis punctorum octo obsoletis, lunulisque rubris, anticâ humerum, posticâ apicem amplectentibus. Pedes nigro-picei.

Oвs. This species comes very near to the genus Erotylus, in general habit and the structure of the tarsi.

\section{Genus HELOTA. Nobis.}

Antennce vix capitis longitudine, sub clypeo ad mandibularum basin insertæ, undecimarticulatæ, articulo basilari sub-obconico crasso, secundo subgloboso, tertio obconico longiore ; clavâ crassâ tomentosâ compressâ orbiculari tri-articulatâ.

Labrum membranaceum sub clypeo occultum, margine lineari vix apparente.

Mandibulce subtrigonæ, validæ, corneæ, extus rotundatæ, apice acutæ, intus sub-emarginatæ tenues.

Maxilla breves, ad basin corneæ, subtrigonæ, apice submembranaceæ, laminatæ, truncatæ, subquadratæ, 


\section{ANNULOSA JAVANICA.}

subquadratæ, ciliatæ: processu dorsali palporum longitudine, basi subcorneo, apice membranaceo, ciliato.

Palpi maxillares articulo primo obconico, secundo pateriformi, tertio vel ultimo præcedentibus simul sumptis fere longiore, subsubulato.

Palpi labiales clavati, vix labio longiores, articulo primo subgloboso, secundo obconico, tertio vel ultimo maximo crasso cylindrico apice truncato perforato.

Labium membranaceum, medio crassiusculum, apice emarginatım, lobis lateralibns rotundatis ciliatis sub-diaphanis.

Mentum breve, latum, corneum, transverso-quadratum.

Caput horizontale subtrigonum clypeo antice rotundato. Thorax magnus subquadratus, supra convexiusculus, posticé lobatus. Scutellım minimum. Corpus depressiusculum coxis fere æqué dissitis. Tarsi breves quinque-articulati, articulo primo minimo vix conspicuo, secundo tertio et quarto subtus setigeris, ultimo aliis simul sumptis longiore infra longitudinaliter fossulato, fossulâ ad apicem inter ungues in processum setis duabus instructum desinente.

Genus Buprestidarum habitu quodammodo fruens.

86. VIGORSII. H. supra viridiceneus punctatus, thorace eminentiis loevissimis, elytris geminatim striatis : liturî mediâ flavo-bimaculatâ.

Long. corp. $\frac{7}{10}$.

Caput viridiæneum, antice et ad latera punctatissimum, oculis albis, collo subtus testaceo, antennis basi piceis apicem versus nigrioribus, et clavæ obscuræ articulo ultimo rufescente. Thorax viridiæneus, punctatus, lineis duabus mediis postice confluentibus, et maculis duabus lateralibus nigris nitidissimis eminentibus. Scutellum nigrum. Elytra viridiænea, striis punctorum geminatis, et latera versus lineis elevatis; liturâ mediâ longitudinali nigrâ maculis duabus magnis flavis læxvioribus insigni. Corpus totum subtus testaceum nitidum. Pedes testacei geniculis et unguibus nigris.

Hac species ab amico tam rei entomologica perito quam studioso $N$. A. Vigors Armigero nomen mutuatur.

Oвs. This insect presents perhaps one of the most curious and novel forms of the whole collection. Its brilliancy and variety of colour, its beauty of sculpture and its similarity at first sight to the Linnean genus Buprestis, altogether render it a most extraordinary insect to be placed among the Necrophaga: yet it cannot be doubted that the true place of this curious insect is in this stirps. The only other insects to which it bears any similarity are the Buprestidce, aud it will prove perhaps, by reason of the strong relation of analogy which it bears to this groupe, most useful in shewing their place in their own tribe. That it does not, however, belong to the Buprestidee clearly appears from its horizontal head, the lateral insertion of its clavate antenna, the structure of the lower surface of its body, and above all from its organs of manducation. In all these particulars, on the other hand, it agrees witl the general characters of the Necrophugrt, some of which, such as the genus Languria, display a similar brilliancy of colour, and a form even more longitudinal. Near to this genus, therefore, and to Dacne I conceive HelotaVigorsii to come, since it also agrees with the latter in the form of its antennæ and structure of montl. The feet nevertheless are constructed differently from those of both these genera, for although onr insect is with still greater difficulty detected to be pentamerous, the minute evanescent joint 
is not as with Dacne and Languria the fourth but the first. Languria and the insects immediately allied to it differ from the typical characters which I have ventured to attribute to the aberrant groupe of Necrophuga, inasmuch as the clava of their antenna is often composed of more than three joints and sometimes even of five. Helota, however, as before said, has its antennæe and mouth similarly constructed with those of the more typical insects of the stirps or at least with Dacne, to which it is much nearer allied than to Engis.

The dorsal process of the maxilla is also in this genus beautifully distinct, and even presents a trace of being articulated. This circunstance of itself as well as the number of joints in the palpi scparates Helota from the Buprestidoe, and places it in this family, for although other families in other tribes, as I have before shewn, may analogically present the bilobed maxilla, and thus approach to the typical structure of that organ, the pieces of the maxilla in all the Buprestida, which I have dissected, are confluent and indeed present a very uniform character wholly different from that of our insect. Moreover the typical character of the maxillary palpi in Coleoptera is that they are quadri-articulate, but in the Necrophaga generally as well as in our insect, the first joint is evanescent, so that such palpi may be described as tri-articulate in which respect they differ wholly from those of the Buprestidoo.

\section{Genus LANGURIA. Lat.}

This genus was established by M. Latreille on the examination of an insect, $L$. bicolor, which was brought from North America by M. Bosc. The genus, however, has not been hitherto properly characterized, since under a high lens it appears to be truly pentamerous, the penultimate joint of the tarsi being very minute, as in Engis. The validity of M. Latreille's generic character will, therefore, depend on his description of the clava of the antennæ, which he considers as consisting of five articulations-a description which, if true, will exclude all the following Javanese species from the geuus. The fact seems to be, that $L$ anguria is divisible into several subgeneru, which may be made to depend on the form of the antennx. Thus fiom the West Indies and Brazil, we have Languria with short antenna, and a very thick clava composed of five joints; while fiom the continent of Iudia, we have such species as Languria elongata Lat. (Trogosita elongata Fab.), which have long filiform antennæ, with a very indistinct atteuuated clava, consisting of three joints. The furm of $\boldsymbol{L}$. bicolor Lat. seems common t' Asia and America. Nevertheless as my object is not to make new genera, but to render new species sufficiently known, I shall leave the following species in the genus Languria, of which I reckon the principal characters to be its linear body, clavate antennæ, filiform maxillary palpi, and evanescent fourth joint of the tarsus.

87. Pyramidata. L. rufo tharacis punctis tribus nigris, capite elytrisque viridi-eneis, anternis chalybeis femoribusque testaceis.

\section{Long. corp. $\frac{3}{5}$}

Caput supra viridiæneum subtus nigrum, antennis chalybeis : clavâ quadriarticulatâ. Thorax rufus margine antico et postico, puncto medio, alioque utrinque laterali nigris. Scutellum nigrum. Elytra pyramidata viridiænea nitida striis punctorum impressa. Abdomen sublineare pyramidatum vel apicem versus gradatim attenuatum, subtus convexum rufum; ano viridiæneo. Pedes chalybei coxis nigris, femoribusque, geniculis exceptis, rufis. 
OBS. A Javanese species described by Wiedemann under the name of $\boldsymbol{L}$. splendens comes very near to this species, and his Languria tripunctata, a Bengal insect, scarcely differs from it except in size and in its feet being altogether of a greenish black colour.

88. Morio. L. nigro-nitida, capite thoraceque punctatis, hoc fossulis duabus linearibus, clytris atro-ceneis puncto-striatis.

Long. corp. $\frac{9}{20}$

Caput nigrum punctatum labro piceo antennisque nigris. Thorax quadratus, punctatus, fossulis duabus brevibus posticis longitudinalibus impressus. Scutellum nigrum. Elytra atroænea striis septem punctorum impressa. Corpus subtus pedesque nigri.

89. TESTACEA. L. nitida, elytris punctato-striatis, antennis pedibusque nigris, coxis femoribusque ad basin ferrugineis.

\section{Long. corp. fere $\frac{3}{10}$}

Insectum supra ferrugineum. Caput subpunctatum, articulo antennarum basilari subferrugineo. Thorax lævissimus. Elytra vix obscuriora striis octo punctorum impressis. Corpus subtus ferrugineum.

OBS. An insect which Fabricius describes from Sumatra, under the name of Trogosita filiformis (Syst. Eleuth. 1, 152, 12), comes very near to the above species ; indeed only differs from it, according to the description there given, in that it has the elytra smootl. This, however, may be an error of Fabricius, as the insect I have described above, under the name of Languria testacea, appears to be widely dispersed, and occurring in my father's cabinet from the continent of India, seems not unlikely to be also a native of Simatra.

This insect clearly shews that Cerylon and other genera of similar structure are most erroneously placed by Latreille with the Bostrichide, for it forms a most complete transition from Languria to Cerylon.

\section{Gemus MEgAUCHENIA. Nobis.}

Antennce capite subduplo longiores, thorace tamen breviores, undecim-articulatæ, articulo secundo crasso obconico, tertio hrevi, quarto longo, reliquis ad clavam brevibus, subglobosis ; clavâ orbiculari compressâ triarticulatâ.

Lubrim exertum, transversum, corneum, apice bilobum, angulis rotundatis.

Mandibulce vix exertæ, depressæ, trigonæ, extus incurvæ, apice acutissimæ intus unidentatæe, et basin versus ciliatæ.

Maxillce basi corneæ processu apicali magno membranaceo falciformi, intus ciliatre, processu dorsali inconspicuo.

Palpi maxillares triarticulati, articulis basilaribus brevibus, obconicis, articulo ultimo oblongo ovali, apice subulato, præcedentibus simul sumptis longiore.

Palpi labiales brevissimi articulo basilari inconspicuo, secundo et tertio obconicis.

Labium membranaceum, apice bilobum, lobis subacutis.

Mentum breve, corneum, basi retusum, apice subtrigonum.

Corpus elongato-guadratum, fere parallelopipedum, depressiusculum. Thorax quadratuo longior quam latior, ab abdomine pedunculo nullo disjunctus. Elytra corpore breviora. 
Tibice ad apicem latiores, extùs denticulatie. Tarsi articulis quinque primis subpulvillatis vel apice setigeris, articulo quarto minimo.

Ons. Megauchenia is a difficult genus, but appears to have a strong affinity to Languric and to Cerylon, indeed principally differs from M. Latreille's description of this last, according to what I have been able to observe, in having the clava of the antennæ of three distinct joints with the labrum emarginate, and, in being pentamerous, in which last respect it agrees with Languriu. I suspect, however, that the Xylophagi of Latreille (which at present form a most artificial assemblage) are in general pentamerous, and that it is merely owing to the minuteness of the fourth joint, and to the small size of the insects themselves, that they have been placed by the entomologists of the French school between the Linnean genera Curculio and Ceramby $x$-groupes between which the transition is immediate and perfect. "Natura opifex rerum, non facit saltus."

It is in this stirps, as has been before said, that we find the maxillæ l'ecede the farthest from their typical form; it is in this stirps therefore that of the whole tribe we find the most herbirorous insects. This is curious, certainly, but corresponds with an observation to be made on the herbivorous tribes of Coleoptera, namely, that where in an herbivorous groupe such as the Petalocera, we meet with a family such as the Trogilce endued with an appetite for animal matter, we find its maxillæ approaching in structure to those of the Adephag $a$, or at least to be furnisherl with 'two processes.

90. SETIPENNIS. M. atropiceus, capite thoraceque subsetigero punctuto-striatis : striis alternatim setigeris.

Long. corp. $\frac{3}{10}$.

C'aput clypeo anticé marginato, antennis piceis clavâ tomentosâ. Thorax marginatus lateribus rugosulis. Elytra punctorum seriebus striata setisque brevibus spiniformibus instructa. Corpus subtus Pedesque picei. Tarsi sub-pulvillati.

\section{Genus SYLVANUS. Lat. Dermestes Lin. Fab.}

This genus is said to have some relation to Trogosita, but on the nature and value of such relation, I am not at present able to offer any decided opinion. It may, however, be observed, that M. Latreille has described Silvamus as having two processes to the maxillix, and Trogosita as possessing only one. Such a remark may lead us to suspect a relation between Silvamus and the Cucujidce, which is not improbable; but however this may be, I repeat that a great portion of doubt must still hang over this arrangement of Latreille's Xylophagi, inasmuch as we know not how many of them truly belong to the stirps of Necrophaga. No greater service can indeed be rendered to this part of entomology than by accurately dissecting these minnte insects, of which so many genera and species are to be found ix England; I question, however, whether it may be advisable to attempt at present a natural arrangement of them, because so few of the exotic species are known, and such wide chasms appear between several of the known genera.

91. Denticulatus. S. ficcus, thorace crenato punctulato: lineis duabus impressis, elytris punctato-striatis, antenuarum clavâ quadriarticulatô.

$$
\text { Long. corp. } \frac{7}{40} \text {. }
$$

Insectum S. sexdentato majus. Caput clypeo punctulato utrinque ante oculos unidentato antennis fuscis. 
Thorax lateribus sexdentatis, dorso subcarinato, fossulâ utrinque longitudinali anticé posticéque profundiore. Elytra pallidiora punctorum seriebus striata. Corpus fuscum pedibus fuscis.

OBs. The Dermestes sexdentatus of Fabricius, which is the same with his Colydium frumentarium and the Ips frumentaria of Olivier, but which appears different from the Corticaria frumentaria of the Entomologia Britannica, comes so vely near to our species that I lave little doubt of its food being analogous. It probably infests rice, as other species of the genus are found in moist sugar.

Genus TRIBOLIUM, Nobis. CoLYDIUM Herbst.

Antennce undecim-articulatre, sub clypeo ad mandibularum basin insertæ, articulis basilaribus octo globosis sub-æqualibus, apicem versus vix crassioribus, tribus ultimis clavau laxam efformantibus; articulis nono et decimo subpateriformibus, ultimo transverso ovali. $O$ s sub clypeo plano transverso ad latera rotundato absconditum.

Oculi clypeo fere cincti. Thorax transverso-quadratus submarginatus. Corpus depressiusculum sublineare. Tarsi articulis quinque.

OBs. This genus appeais closely allied to Colydium and also to have some sort of relation to Colobicus. From the latter it differs in the antennæe and form of body; from the former in the form of head and in being pentamerous. I am indeed inclined to think that the Colydinum rufum of Latreille (Gen. Insect. et Crust. Vol. 3. p. 21.) belongs to this genus, if it be not identical with our species; but the description of the Colydium rufum by this entomologist is too vague to admit of certainty on the subject.

As the specimen is unique in the collection of the East-India Company, I have been under the necessity of contenting mysclf with a generic description founder on external characters alone.

Herbst has very justly remarked the strong connexion which exists between this geuus and Dermestes, and there is indeed no doubt of its belonging to the stirps of Necrophaga, as its larva scarcely differs from that of Dermestes except in not being so hirsute.

92. CASTANEUM. T. ferrugineum, capite thoraceque subtilissimé punctatis, elytris punctato-striatis.

Colydium castaneum Herbst. 7. 282. tab. 112. fig. 13. E.

An Colydium rufum, Lat. Gen. Ins. et Crust. vol.iii. p. 21 ?

An Colydium rufum, Fab. Syst. Eleuth. 2. 55\%.11?

Trogosita ferruginea, Fab. Syst. Eleuth. 1. 155. 23.

Ips testacea, Fab. Ent. Syst. Suppl. 179. 14?

Synonymia Trogosita ferruginea apud Fabricium corrigenda, antennarum enim clava in Lyclo navali Ent. Syst. 1.2. 504. 10, est biarticulata.

Long. corp. $\frac{7}{40}$.

Clypeus ante oculos depressus angulis truncatis. Antennce apice pallidiores. Thorax fossulâ utrinque ad marginem posticum impressâ. Elytra seriebus punctorum inter strias duabus obscuré impressa. Corpus subtus obscuro-piceum pedibus rufis.

OBs. This insect is by Fubricius stated to be most destructive to rice, that is if it be the Ips testacea of the Supplement, but of this I have great doubts, as the description is so loose and vague that it might suit a Sylvanus. I have, however, found the Tribolium rufum alive among insects from India, and according to Herbst it is very destructive in such situations, he having received 
received it as, he says, an uninvited guest in a collection of insects from the East-Indies. Fabricius says of his Trogosita fermginea "Habitat in Indiâ utrâque destruens animalia in Museis asservata, panem, aliaque." The name of $X$ ylophagi given to this groupe of insects by Latreille, seems indeed to be one of the most inappropriate that he could have chosen, since I do not know that there is any ascertained instance of a species devouring wood. He grouped them, however, with the Bostrichida, to which they have little or no immediate affinity, and which are true Xylophagi. Many of the present insects indeed are to be found under bark, but this residence may be owing to their taste for the fungi and dead animal matter which usually abound in such situations. Those with the habits of which we are acquainted devour fruits, corn, and decayed animal matters. Thus the celebrated Degeer ascertained that his Tenebrion du lard, which is a species of Latridius, in its larva state devours bacon. The figure and description of this larva proves satisfactorily that these insects are properly placed among the Necrophaga and near the Dermestidce. There appears moreover to be a strong relation of analogy between the form of Latridius and certain species of the contiguous stirps of Philhydrida, such as for instance the Hydrcence among the Elophoridce.

The Tribolium castaneum is often to be found in collections as an English insect, but is only, as I suspect, a visitor of our island.

\section{Fam. 5. DERMESTID IE.}

That this family was in the opinion of Linnæus closely connected with the last, sufficiently appears from the following sentence in his Biga Insectorum, "Unde patet gener"a insectorum nova admodum esse rara, nisi ante cognita quispiam vellet separata ut Hydroum a Dytiscis, Ipsidem a Dermestibus." In several genera of the last family the mandibles are short and thick, concealed under the clypeus, and in these insects the mandibles are always of this construction.

Herbst has given an excellent magnified figure of the larva of the common Dermestes and this figure sufficiently proves that we are here at the very extremity of Chilopodiform larvæ. It is indeed from this family that we proceed to the neighbouring tribe of Chilognathiform larvæ.

Genus DERMESTES. Lin.

93. VuLPINUs. D. niger subtus albidus capite thoracisque lateribus cinereo-villosis, scutello testaceo-villoso, elytris submurinis.

Dermestes vulpinus. Fab. Syst. Eleuth. 1. 314. 12.

Long. corp. $\frac{7}{20}$.

OBs. This destructive insect appears to be very generaliy dispersed over the old world. It is at least too common in France, the whole of the south of Europe, Africa, and India. In my father's collection there is also one marked as from Cayenne. The ubiquity, however, of such insects as these which inhabit skins, \&c. may be owing to their attendance on man.

Genus CHELONARIUM. Fab.

94. VILLosUm. C. nigropiceum nitidum subpunctatum, elytris substriatis, tarsis rufescentibus, antennarum articulis ultimis pallidis.

Long. corp. $\frac{1}{4}$.

Insectum totum villo denso cinereo obtectum.

OBs. 
OBs. The occurrence in Java of genera like this, hitherto supposed to be peculiar to America, is a circumstance important in entomological geography, and which we shall frequently have occasion to allude to. In the mean time I shall observe that the antennæ of the only specimen in the East-India Company's collection have lost their last joints, having only two of that setiform part which so singularly distinguishes this genus from all other's known. (Vide Lat. Gen. Ins. et Crust. Vol. 2. p. 44.) Such antennæ agree in scarcely any respect with those of other Chilopodomorpha, and I am therefore by no means convinced of the propriety of placing this insect here, and must consider the matter as undecided until a more accurate investigation shall have been made from an unmutilated specimen.

\section{Stirps 5. BRACHELYTRA. Lat.}

It is a singular circumstance that no insect of this stirps, which is the same as the Linnean genus Staphylinus was collected by Dr. Horsfield. This at all events proves the extreme rarity of such insects in Java. Of their existence in the island I have no doubt, since they have been brought both from New Holland and the Continent of India, and it would therefore be remarkable did they not occur in the intervening islands. When it is considered that the British species of this stirps are so numerous, it appears very extraordinary that not one should have occurred in Java. But in this, as in all other tropical climates, the surface of the earth is almost exclusively occupied by ants, and according to Dr. Horsfield, where the common ants are not found the Termites or white ants possess the territory. These two tribes, which are constantly at war, or rather, which clear away and destroy each other as their numbers respectively predominate, have in a great measure divided the surface of the island among themselves. From their incredible numbers, particularly of the common ant, little is left on the surface for other insects. Swarming on every.spot, and incessantly in motion, they attack and devour whatever animal matter they meet with in a much shorter period than would be thought possible by a person who had not witnessed the fact. But nevertheless whenever in his excursions Dr. Horsfield observed the carcase of any animal, he and his assistants carefully examined it, and from the care they took in such labours, he is convinced that had Silphida, Staphylinidce and such carrion-feeding families of insects occurred in any tolerable abundance, they could scarcely have escaped his researches. With respect to such genera of Brachelytra as inhabit flowers, he scarcely conceives, had they been common, that they could have escaped him, as he was in constant habit of collecting on plants and flowers.

In the third volume of the Règne Animal, M. Latreille has divided his groupe of Brachelytres into four sections, which he terms Fissilabres, Longipalpes, Applatis and Microcephales, all of which are apparently natural groupes. Now if to these we add his grand division of Dimerous insects, we have the whole of the Brachelytra, which may therefore be arranged thus:

\section{BRACHELYTRA.}

$$
\begin{aligned}
& \text { 2. Aberrant groupe? } \\
& \text { Caput haud thoracis } \\
& \text { magnitudine. } \\
& \text { 1. Normal groupe? } \\
& \text { Caput thoracis } \\
& \text { magnitudine. }
\end{aligned}
$$

$\begin{cases}\text { 5. Tachyporida, } & \text { vel } \\ \text { 4. Pselaphide, Leach } & \text { vel } \\ \text { 3. Omalida, } & \text { vel }\end{cases}$
$\begin{cases}\text { 2. Stenida, } & \text { vel } \\ \text { 1. Staphylinida, } & \text { vel }\end{cases}$

\author{
Microcephales Lat. \\ Dimera Lat. \\ Applatis Lat. \\ Longipalpes Lat. \\ Fissilabres Lat.
}


The apparently dimerous tarsi of the Pselaphida are not of themselves alone sufficient to throw these insects out of the stirps, for we nay perceive the articulations of the tarsi to disappear in Oxytelus and several genera of the neighbouring family, which the Tarsal System with its usual inconsistency, places widely apart from the $P$ selaphida.

From the Omalide by means of the genus Lesteva, we return to the Geodephaga into which stirps we enter by Lebia and other of the Brachinida, a family of which the distinguishing or typical character depends on an approach to the short truncated elytra of the Brachelytra. In Lesteva, moreover, and such other genera of this stirps as come nearest to the Geodephaga, the outer process of the maxilla is slender and palpiform. So it is that, whether nature be regarded at the root or at the extreme branches of her tree, we always find her pursuing the same plan, and constantly displaying as much unity as beauty. 
Thrs Work, which is intended to eontain systematic Descriptions of all the Insects collected by Dr. Horsfield in Java, will be published in Numbers. The Species will be arranged, as nearly as possible, according to their natural affinities; and in order to make this, the important part of the Science, more clear, the Descriptions will be interspersed with such leading observations on the economy and anatomical structure of the Families, as may, it is hoped, render the work interesting to Naturalists in general, as well as to the Entomologist.

The plan of the Anthor, however, will be best understood on a perusal of the first Number. The second Number is now in progress for publication, and will contain the whole of the Coleoptera having Iuliform Larvæ.

The Insects described are arranged in the Museum of the Honourable East-India Company, where they may be inspected under the regulations established at their Library.

PEEDILY WILL BE PUBLISHED,

\title{
PLANTE JAVANICA RARIORES,
}

\author{
DESCRIPTE ICONIBUSQUE ILLUSTRATE,
}

QUAS IN INSULA JAVA, ANNIS 1802-1817, LEGIT ET INVESTIGAVIT

THOMAS HÓRSFIELD, M.D. S.L. et G.S.

\section{DESCRIPTIONES ET CHARACTERES,}

E SICCIS ELABORAVIT,

Nec non Observationes de earum Structura et Affnitatibus passim adjecit, ROBERTUS BROWN, S. R. et L. S., \&c. \&c. \&c.

IN this Work will be given Figures and Descriptions of the more remarkable new or imperfectly known Plants, contained in a Herbarium of Two Thousand Species, collected in the Island of Java, by Dr. HarsFreLD, and deposited by him in the Museum of the Honourable East-India Company.

The size of the Work will be a large Quarto. Each Plant will be figured on a separate Plate; the subjects selected wrill not exceed One Hundred; and the Work will appear in Numbers, containing Eight Plates.

Both the Engravings and Descriptions are in a state of forwardness, and it is proposed to publish the first Number early in the course of the present season. 